\title{
Nemoral species of Lepidoptera (Insecta) in Siberia: a novel view on their history and the timing of their range disjunctions
}

\author{
V. V. Dubatolov \& O. E. Kosterin
}

Dubatolov, V.V. \& Kosterin, O.E. 2000: Nemoral species of Lepidoptera (Insecta) in Siberia: a novel view on their history and the timing of their range disjunctions. - Entomol. Fennica 11: 141-166.

Distributions in Siberia of nemoral lepidopteran species, trophically or cenotically tied to broad-leaved (nemoral) forests or their phytocenotic derivates, display seven main types of range: Amphipalaearctic; Europe - West-Siberia - Far-East disjunctive; East-Europe - Altai - Far-East disjunctive; Altai - Far-East disjunctive; South-Siberia - Far-East; Transbaikalia - Far-East; Europe - Transuralia. An eastern origin can be traced for most of these species, with the exception of the last-mentioned type. According to palynological data, a continuous belt of broad-leaved forests was re-established during the Quaternary in North Eurasia at least twice: at the beginning of the Late Pleistocene and in the Middle Holocene. During the former the range of oak, as well as the fauna connected with it, was continuous through the Palaearctic. There is no reliable evidence for refuges of nemoral flora and fauna in Siberia during the last glaciation. We assume that the period since the Late Pleistocene (Kazantseva) Optimum (about $100,000-110,000$ years) was sufficient for taxonomic divergence to species rank of western and eastern Palaearctic populations of Lepidoptera. During the Holocene climatic optimum the lepidopteran nemoral fauna could expand into a transpalaearctic distribution as a consequence of westward migration of eastern species due to an earlier optimum of broad-leaved forests in the eastern parts of Asia than in West Siberia and Eastern Europe. Disjunctive types of nemoral species range may have resulted from depletion of the forests with broad-leaved trees in Central Siberia during the Subboreal period of the Holocene. Thus, they should not be dated to the late Pliocene - early Pleistocene, as was done earlier.

V.V. Dubatolov, Siberian Zoological Museum, Institute of Animal Systematics and Ecology of Siberian Division of Russian Academy of Sciences, Frunze street, 11, Novosibirsk 630091, Russia.

O.E. Kosterin, Institute of Cytology and Genetics of Siberian Division of Russian Academy of Sciences, Academician Lavrentiev avenue, 10, Novosibirsk 630090, Russia.

Received 8 November 1999, accepted 15 February 2000 


\section{Introduction}

\subsection{General}

The overwhelming majority of Lepidoptera are phytophagous in the larval phase, and their communities are closely associated with particular vegetation types. This is especially clear for the nemoral fauna, which inhabits broad-leaved (nemoral) forests. We report an analysis of ranges in Siberia of lepidopteran species which can be regarded as nemoral or as tied trophically or cenotically to broad-leaved forests or their analogues. We use the term 'broad-leaved' for trees and forests of the nemoral complex, including the oaks, ashes, elms, lime-trees, hornbeams, walnut, etc. but exclude those of the so-called betular complex, e.g. the birches, willows and poplars, which, at least in the Russian floristical and geobotanical tradition, are called 'small-leaved trees'.

Since broad-leaved forests proper are practically absent from most of Siberia, there are rather few nemoral lepidopteran species, and their ranges often have large gaps. The age of these gaps used to be dated to the Pleistocene or to the end of the Pliocene - which, to our opinion, is an overestimate. There is reasonably rich literature on the formation of the insect fauna of the taiga zone (Florov 1955), as well as the postglacial migration of boreal species (Mikkola 1987, 1988, Mikkola et al. 1991). By contrast discussion of the history and migrations of nemoral species in North Eurasia has hardly begun (Kononenko \& Mikkola 1992).

\subsection{Broad-leaved (nemoral) trees in Siberia at present}

Zonal vegetation of relatively warm and humid regions of the temperate zone of Eurasia is represented by broad-leaved deciduous forests ("hardwood" in North America) or mixed coniferous/ broad-leaved forests. For their characteristic flora the term 'nemoral flora' is widely accepted, some authors using the phrase 'nemoral forests' for this vegetation type. In these forests the dominants are genera, in Russian not so precisely called broad-leaved trees, like oak ( $Q$ uercus), elm (Ulmus), lime or linden (Tilia), beech (Fagus), maple (Acer), ash (Fraxinus), hornbeam (Carpi$n u s$ ), and walnut (Juglans). At present the broadleaved or mixed coniferous/broad-leaved forests do not form a continuous belt in Eurasia, but occur in the western (Europe and to some extent Asia Minor and Iran) and eastern (southern temperate East Asia) parts of the continent. In the west they are mostly represented by mono- and oligo-dominant broad-leaved forest while in East Asia they are mostly polydominant (oak, linden, hornbeam, maple, elm, fir, spruce, Korean stone pine) mixed coniferous/broad-leaved forests, retaining features of the ancestral Tertiary forests of the so-called Turgai flora (Krishtofovich 1958, Kleopov 1990). In the north of Eurasia the belt of broad-leaved forests is interrupted by a sizeable gap embracing practically the whole of Siberia, while further south it is interrupted by the arid regions of Central Asia and the Middle East.

The species composition of the Siberian deciduous forest is strikingly poor. Only two genera, Betula (birch, a few very closely related species of aff. Betula alba L. s. 1.) and Populus (one species, aspen, Populus tremula L.) are dominant in the deciduous and mixed forests and foreststeppe groves (Shumilova 1962). In Russian these forests are traditionally known as 'small-leaved', which corresponds to the North American term 'softwood', while the flora connected with them has been called a betular flora (Kleopov 1990). Representatives of four other deciduous tree genera common in Siberia either form only azonal riparian stands (a number of willows (Salix) and some poplars (Populus)), or are small trees of the understorey (some other willow species, bird cherry (Padus avium Miller), Siberian rowan tree (Sorbus sibirica Hedl.)). It is noteworthy that in NW Eurasia the eastern border of such broad-leaved species as the oak and maple and to some extent elm and linden coincides with the relatively low mountains of the Urals (Gorchakovskii 1968). A key factor limiting the spread of the broad-leaved species further eastward is the insufficient humidity (Gorchakovskii 1968). Presently Siberia lacks natural communities of such trees as maple, hornbeam, beech, ash, and walnut. In West Siberia even the arboreal alders (Alnus s. str.) are very rare: $\mathrm{Al}$ nus glutinosa (L.) Graeth. and A. incana (L.) Moench. are very locally found in the westernmost parts only (Shemberg 1992), and in East 
Siberia the genus is represented by A. hirsuta (Spach.) Turcz. ex Rupr. s. 1.

Forests of southern-taiga type which include some broad-leaved tree species remain in Siberia only very locally (Fig. 1). In the western West Siberian Lowland elm (Ulmus laevis Pall.) penetrates from the Urals almost to Tyumen, and lime (Tilia cordata L.) extends eastwards to the River Irtysh, along which it extends south to Tara (Gorchakovskii, 1968). There is a large isolate of pure lime forests (the so-called 'lime island') in the foothills of the uplands of Gornaya Shoriya (the southern Kemerovo Province). A few small isolated growths of lime exist in the Provinces of Kurgan, Novosibirsk, Tomsk, Altaiskii Krai, and in the environs of Krasnoyarsk (Khlonov 1965; Polozhii \& Krapivkina 1985). In East Siberia (in Southern and Eastern Transbaikalia), three species of elm occur (Ulmus pumila L., U. macrocarpa Hance, $U$. japonica (Rehd.) Sarg.), while the westernmost isolated Mongolian oak (Quercus mongolicus Fischer ex Ledeb.) is found on the lower reaches of the River Argun' (Krasnoborov 1992). In addition the Siberian apple-tree (Malus baccata Borkh.) occurs east of the southern Baikal region (Kurbatskii 1988). As to be expected from the scarcity of broad-leaved forests in Siberia, their characteristic insect fauna is greatly impoverished or altogether missing. The eastern boundary of the ranges of many European nemoral species, as well as of the broad-leaved tree species, coincides with the Ural mountains, while there exist a greater number of western boundaries for the Far Eastern species which penetrate into Siberia.

\subsection{Former conceptions of the Amphipalaearc- tic disjunctions and the timing of their origins}

The disappearance of the continuous broad-leaved (nemoral) forest belt in Siberia and the subsequent formation of disjunctive ranges of plant species has traditionally been linked to the Pleistocene glaciations (Matyushkin 1982). The nemoral species remaining in Siberia were considered 'Tertiary relics' (Kuminova 1938, 1951, 1957, Peshkova 1984, Polozhii \& Krapivkina 1985). Similar$1 y$, numerous authors believed that many nemoral insect species survived the most severe spells of the Pleistocene in South Siberian refuges, for instance Odonata (Belyshev \& Haritonov 1978, 1982, Kosterin 1987), Diptera (Gorodkov 1979), and Lepidoptera (Mikkola 1987). Accordingly, the climatic deteriorations of the Pleistocene were thought to be the driving force in forming the disjunctive Amphipalaearctic species ranges (with separate western and eastern ranges in Eurasia) of birds (Stegmann 1938, Matyushkin 1982), Homoptera (Anufriev 1979), Lepidoptera (Zolotarenko 1981, 1994, Korobeinikov et al. 1990, Kononenko \& Mikkola 1992), and jumping spiders (Logunov 1996). Although the fact that Amphipalaearctic ranges are exhibited by taxa of different rank has already been recognized (Matyushkin 1976) - from different genera within a family to populations without even subspecific differences - the date of the disjunctions was either not investigated (ibid.) or was estimated speculatively without analysing thepPalaeontological data. The formation of intrageneric disjunctions, with clear-cut congeneric species in the western and eastern parts of Eurasia, used to be assigned a pre-Pleistocene date (Anufriev 1979). For instance, in the Odonata such disjunctions were believed to have formed in the Palaeogene (Belyshev et al. 1989), while younger (intraspecific) disjunctions were considered to have resulted from Pleistocene glaciations and climatic deteriorations (Anufriev 1979). Unequivocal dating of such disjunctions requires an analysis of palaeontological data (Eskov 1984), which are unfortunately lacking in our case. However, the assocations between the nemoral species and the broad-leaved forest vegetation enables us to infer a putative history of their ranges from that of the corresponding tree species.

\subsection{The history of forest vegetation in Siberia in the Late Cenozoic}

During the last 10-15 years Russian palaeobotanists and palynologists collected and summarised vast amounts of material, but their conclusions are still insufficiently known among zoologists. These data require a complete revision of the former view of the history of broad-leaved forests in Siberia (Neischtadt 1957, Matveeva 1968, Matyushkin 1982). Since most of these data are published in Russian and often in publications little known even in this country, we give here a 
short review of the history of forest vegetation in Siberia from the end of the Neogene until the Holocene.

The Neogene (the middle and upper part of the Tertiary) was in general warmer than the Quaternary. Thus, in the Pliocene, remnants of polydominant broad-leaved forests of the Turgai flora still grew throughout Siberia as far as the Chukotka Peninsula (Belova 1985, Fradkina 1995). In the Late Pliocene the climate became much cooler. Mountain glaciations and tundra appeared in NE Siberia (Fradkina 1995), but a thermophilic flora, including broad-leaved trees, still occupied southern Siberia (Belova 1985). The latter included such thermophilic tree genera as Tsuga, Celtis, Magnolia and Fagus, recently extant in the southern temperate and subtropical regions of East Asia, and also Juglans, Ilex, Tilia, Carpinus, and Acer, now found in Amurland as the most northerly part of their range. Many thermophilous trees occurred in Kamchatka (Boyarskaya \& Malaeva 1967, Rusanov 1967, Belova 1985), and according to some records, the pollen of some broadleaved trees are occasionally found as far north as the Kolyma River (Bespalyi 1984).

In the Russian stratigraphic nomenclature the Quaternary is subdivided into three divisions: the Eopleistocene (1.65 million to $800,000-700,000$ years BP), Pleistocene $(800,000-700,000$ to 10,000 years BP) and Holocene $(10,000$ years BP to the present) (see Table 1). The Eopleistocene is poorly studied in Siberia, with only scarce information from West Siberia (Arkhipov \& Volkova 1994). It began with the Gorno-Filino optimum $^{1}$. For this period no arctic or subarctic plants have been recorded from the territory now occupied by the middle taiga zone. On the other hand, such broad-leaved trees as elm and linden were widely distributed. ${ }^{2}$ During this optimum, forests comprising many thermophilic trees, including Tsuga, Pterocarya and Fagus, occurred almost throughout Eastern Europe (Grichuk 1989). Later, in the Talagaika period, the climate and vegetation zones in West Siberia resembled the modern ones (Archipov \& Volkova 1994).

During the Lower and Middle Pleistocene large periodic climatic variations were recorded for Siberia (Table 1), the warm periods being cooler than the interglacial optimum of the Upper Pleistocene (Belova 1985, Arkhipov \& Volkova 1994). Since these climatic changes took place in the remote past, they are less relevant to the understanding of the formation of the recent species ranges.

The Upper Pleistocene began with a very warm Kazantseva Interglacial, corresponding to the Mikulino Interglacial in the East European and the Riss-Würm Interglacial in the West European system (Table 1); it lasted from 120,000 to 95,000 years BP. According to palynological data, forests comprising oak, elm, and linden occured widely throughout South Siberia at this time (Belova 1985, Arkhipov \& Volkova 1994), apparently forming a continuous belt extending to $60^{\circ} \mathrm{N}$ (to the Podkamennaya Tunguska River) (Fig. 9). Even thermophilic Juglans and Tsuga grew on the Khamar-Daban Mts. (the shores of Lake Baikal); Tsuga was also quite abundant on the Chara River in NE Transbaikalia (Belova 1985). The oak, elms and linden ranged as well throughout NE Mongolia, including the Hangai Mts. and perhaps further west (Golubeva 1978, Shilova 1981). Various palynological studies (Belova 1985, Bakhareva 1985, Arkhipov \& Volkova 1994) indicate that during this period oak had a continuous transpalaearctic range (Fig. 9). According to Menitskii (1982), the range of oaks of the Quercus robur L. group was continuous in North Eurasia as long ago as in the Miocene, but the very close taxonomic relationship of the modern taxa Q. robur L. (Europe and Asia Minor) and Q. mongolica Fischer (temperate East Asia) suggests, in our opinion, a more recent isolation.

After the Kazantseva Interglacial one of the coldest periods of the Pleistocene in Siberia began - the Zyryanka Glacial - corresponding to

\footnotetext{
${ }^{1}$ Here we use the nomenclature for the periods of the Pleistocene accepted for Siberia, for its correspondence with the East- and West-European systems see Table 1.

${ }^{2}$ Species names reported in some palynological works devoted to the Pleistocene and Holocene have been mechanically and from the recent flora, but in our sketchof the distribution of the broad-leaved forests in the Quaternary we consider only their genera since the palaeopalynological methods often do not allow species identification (V. S. Volkova, personal communication). Many recent tree species are relatively young and it is not so clear that they have diverged on the species level in that remote past.
} 
Table 1. Geochronological table of the end of Cenozoic. According to: Grichuk, 1989; Arkhipov, Volkova, 1994; Vereshchagin, Mironova, 1982; and Volkova, pers. com.

\begin{tabular}{|c|c|c|c|c|c|c|}
\hline \multirow[t]{2}{*}{ Period } & \multirow[t]{2}{*}{ Epoch } & \multirow{2}{*}{$\begin{array}{l}\text { Sub- } \\
\text { epoch }\end{array}$} & \multicolumn{3}{|c|}{ Time } & \multirow{2}{*}{$\begin{array}{c}\text { Absolute date } \\
\text { (thousand years ago) }\end{array}$} \\
\hline & & & Western Europe & Eastern Europe & Siberia & \\
\hline Quaternary & $\begin{array}{l}\text { Pleistocene } \\
\text { Eopleistocene }\end{array}$ & $\begin{array}{c}\text { Late } \\
\text { Middle } \\
\text { Early } \\
\text { Late }\end{array}$ & $\begin{array}{c}\text { Late Würm } \\
\text { glaciation } \\
\text { Middle Würm thermal } \\
\text { Early Würm } \\
\text { glaciation } \\
\text { Riss-Würminterglaciation } \\
\text { Varta glaciation stage } \\
\text { thermal } \\
\text { Riss glaciation } \\
\text { Mindel-Riss interglaciation } \\
\text { Mindel glaciation } \\
\\
\text { Günz-Mindel (Kromer) } \\
\text { interglaciation } \\
\text { Günz glaciation }\end{array}$ & $\begin{array}{c}\text { Subatlantic } \\
\text { Subboreal } \\
\text { Atlantic } \\
\text { Boreal } \\
\text { Preboreal } \\
\text { Late Valdai (Ostashkov) } \\
\text { glaciation } \\
\text { Middle Valdai } \\
\text { interglaciation } \\
\text { Early Valdai } \\
\text { (Kalilin) glaciation } \\
\text { Mikulino interglaciation } \\
\text { Moscow glaciation } \\
\text { Odintsovo (Roslavl) } \\
\text { interglaciation } \\
\text { Dnieper glaciation } \\
\text { Likhvin interglaciation } \\
\text { Berezina (Oka) glaciation } \\
\text { Naliboki (Venedy) thermal } \\
\text { Dzukia (Don) glaciation } \\
\text { Brest interglaciation } \\
\text { glaciation }\end{array}$ & $\begin{array}{c}\text { Late Zyryanka } \\
\text { (Sartan) glaciation } \\
\text { Karginskii thermal } \\
\text { Early Zyryanka } \\
\text { (Ermakovo) glaciation } \\
\text { Kazantseva interglaciation } \\
\text { Taz glaciation } \\
\text { Shirta interglaciation } \\
\text { Samarov glaciation } \\
\text { Tobolsk interglaciation } \\
\text { Late Shaitanskii glaciation } \\
\text { Middle Shaitanskii thermal } \\
\text { Early Shaitanskii glaciation } \\
\text { Talagaika interglaciation } \\
\text { Late Avdot'in glaciation } \\
\text { Middle Avdot'in thermal } \\
\text { Early Avdot'in glaciation } \\
\text { Gorno-Filino thermal }\end{array}$ & $\begin{array}{c}\text { From } 3 \text { till present } \\
\text { From } 6 \text { till } 3 \\
\text { From } 8 \text { till } 6 \\
\text { From } 9 \text { till } 8 \\
\text { From } 10 \text { till } 9 \\
\text { From } 23-22 \\
\text { till } 12-10 \\
\text { From } 60-55 \\
\text { till } 23-22 \\
\text { From 110-100 } \\
\text { till } 60-55 \\
\text { From 150-130, till 110-100 } \\
\text { From } 170(?), \text { till } 130-150 \\
\text { From } 200-180 \\
\text { till } 170 \text { (?) } \\
\text { From } 260, \text { till } 200-180 \\
\text { From } 370 \text { till } 260 \\
\text { From } 500 \text { till } 370 \\
\text { From } 600 \text { till } 500 \\
\text { From } 700-800, \text { till } 600 \\
\text { Approximately } \\
700-800 \\
\text { From } 1600 \\
\text { till } 700-800 \\
\end{array}$ \\
\hline
\end{tabular}


the Valdai Glacial in Eastern Europe and the Würm Glacial in Western Europe (Table 1). There were, in fact, two subsequent glaciations, in $\mathrm{Si}-$ beria called the Ermakovsk and Sartan, separated by the Karginskii Interglacial (the Middle Valdai in Eastern Europe and the Middle Würm in Western Europe). In southern Central Siberia (the Kan River mouth, the Irkut River, and the KhamarDaban Mts.) this interglacial was quite warm, with birch and pine forests including some oak, elm and, at the River Selenga, maple (Belova 1985). Analysis of the pollen in food remains found in the digestive tract of the Selerikan Horse - which died in the Karginskii period and was found frozen in the permafrost on the River El'ga in the Indigirka River upper basin - revealed a rich flora including elm, hazelnut and spruce (Ukraintseva 1996), which can now be found only as far south as in the Amurland. In the Karginskii period the broad-leaved trees most probably ranged widely in the south of East Siberia, perhaps even in Yakutia (Ukraintseva 1988). The data for West Siberia are inconsistent: Arkhipov \& Votakh (1973) reported elm pollen in the upper Ob' River valley in the horizon corresponding to 40,000 32,000 years BP, coinciding with the Karginskii period. However, Arkhipov \& Volkova (1994) later stated that pollen of broad-leaved trees have not been found from this time in West Siberia. In Eastern Europe, the broad-leaved trees extended northwards to Petrozavodsk (Grichuk 1989). In general, the Karginskii period in East Siberia was much warmer than in Europe (Ukraintseva 1988).

In the opinion of most experts, during the coldest periods of the Pleistocene the Siberian landscapes differed from any recent ones in being very cold and arid, somewhat analogous to the highlands of Inner Asia. The forest zone was entirely missing (Arkhipov \& Volkova 1994, Belova 1985). Small remnants of the dark-needle (spruce) coniferous forests may have been retained in the southernmost mountainous regions of Siberia (Nazarenko 1990, 1992). The prevailing landscape combined the features of tundra and very cryoxerophytic grassy communities of low productivity, called steppoids (Kozhevnikov \& Ukraintseva 1992). In West Siberia the forestless landscapes of dry tundra type extended as far south as $56^{\circ} \mathrm{N}$ (Fig. 10), with xerophytic forest-tundra present still further south (Arkhipov \& Volkova
1994). In the South of East Siberia there was no evidence for forests, except for the forest-tundra (Belova 1985).

Palaeopalynologists found in Siberia no traces of broad-leaved trees during maximum glaciation, although refuges of nemoral flora and fauna have often been supposed to exist in the North Altai and Kuznetskii Alatau Mts. (Kuminova 1957, Peshkova \& Krapivkina 1985, Ermakov 1998), and in Transbaikalia (Bezrukova 1996).

A number of Russian scientists (Gorchakovskii 1968, Grichuk 1989, Esjunin et al. 1993) assumed a refuge of some broad-leaved trees (oak, lime) and the satellite invertebrate fauna to have existed during the Sartan (Late Valdai, or Late Würm) Glacial in the south-western foothills of the Ural Mts, i.e. at the western border of Siberia. Another, less well-known refuge has been assumed to have existed at Samara, in the middle reaches of the River Volga (Grichuk 1989). According to Grichuk, a meadowy forest-steppe with oak, elm, and linden existed locally in the River Dniestr basin, in the lower reaches of the River Dnieper, the middle reaches of the Severnyi Donets River, in the Volga River basin from Samara to Saratov, and in the southern Ural foothills, or only $700 \mathrm{~km}$ from the continental ice sheet (Fig. 10). According to Grichuk (1989), broadleaved and mixed coniferous/broad-leaved forests, ranged south to the Crimea and the Caucasus.

On the other hand, according to Arkhipov \& Volkova (1994), in West Siberia the earliest forest vegetation in the form of forest-tundra communities appeared as far as $1200 \mathrm{~km}$ from the ice sheet (Fig. 10) The reconstructions by Grichuk (1989) and Arkhipov \& Volkova (1994) of the vegetation of the maximum Late Valdai (Sartan or Late Würm) Glacial do not correspond for the western main slope of the Ural Mts. For the South Urals Grichuk (1989) reconstructs a mixed smallleaved/coniferous forest with participation of broad-leaved tree species, while Arkhipov \& Volkova (1994) for the eastern main slope of both the South and Middle Urals suggest tundra and forest-tundra. On the other hand, Arkhipov \& Volkova's reconstruction corresponds to that of Belova (1985) for southern East Siberia and to that of Nazarenko $(1990,1992)$ for the Far East, both suggesting only forest-tundra communities in southern East Siberia. According to Moskvitin 
(1962), the permafrost in the Kalinin (Early Würm) Glacial extended southwards to the Caspian Lowland, the 'Khvalynsk Sea' coasts being occupied by a dark-needle (spruce) taiga. Data on the presence of pollen of broad-leaved tree species in the putative refuge of the South Urals during the Würm may result from pollen re-sedimentation (Volkova pers. comm.), other data may refer to the Middle Valdai (Middle Würm, or Karginskii) Interglacial (Smirnov et al. 1990), when broadleaved trees occupied southern West Siberia (Arkhipov \& Votakh 1973), rather than to Late and Early Valdai (Late and Early Würm) Glacials. On the basis of the previous discussion, we doubt the existence of forest refuges with broad-leaved species in the South Ural Mts., adjacent to foresttundra in the West Siberian Lowland, and believe that such refuges have not been proved beyond doubt (see also Gorbunov \& Olschwang (1991)).

After the discovery by Krylov (1891) of pure lime forests, with many (32) nemoral herb and grass species, on the Gornaya Shoria Mts. (the Kemerovo Province), this so-called 'lime island' used to be considered as an undoubted refuge of the nemoral flora in West Siberia (Krylov 1891, Kuminova 1957, 1960, 1963, Ogureeva 1980, Teplyakova 1988, Polozhii \& Krapivkina 1985, Kamelin 1998). Also regions occupied by the peculiar plant community known as chernevaya taiga are considered such refuges (Ermakov 1998). This vegetation formation is characterised by fir and aspen as dominants, with tall herbage enriched with nemoral herbaceous species in the ground layer, and so is considered to be subnemoral forest (ibid.). It grows on low uplands of Salairskii Kryazh and Gornaya Shoria, in West and NorthEast Altai and fragmentarily on the northern slopes of the West Sayan, westernmost East Sayan, and the Khamar-Daban Mts. (Epova 1956, 1961, Shumilova 1962, Polozhii \& Krapivkina 1985, for a map see Ermakov 1998). However, palynological data cited above (Arkhipov \& Volkova 1994) suggest the absence of lime and other broad-leaved trees during maximum glaciation at least in southern East Siberia. Unfortunately, information on the vegetation of the Gornaya Shoria and West and North-East Altai during glaciations is so far unavailable.

During maximum glaciations of the Late Pleistocene, zonal forests existed 'between the Turgai and the Aral' (Arkhipov \& Volkova 1994). According to V. S. Volkova (pers. comm.) they corresponded to the recent northern taiga forests. Hence, the forest zone shifted more than $10^{\circ}$ southwards, as compared with its recent situation. Forests occupied the mountains of northern Central Asia, with dark-needle forests in the North TienShan Mts. and broad-leaved ones in the West TienShan and Alai-Pamir Mts. (Nazarenko 1990, 1992). In the Far East the broad-leaved forests remained in the present-day Japan (in that time united with the continent), western Korea, and the eastern Chinese coast (Nazarenko 1990, 1992). An analogous refuge should have existed in Transcaucasia, where in the Lenkoran Lowland an extremely rich dendroflora of the Turgai type still exists.

The amelioration of the climate began 17,000 years ago and led to the disappearence of the continental ice sheet (c.10,000 years BP) and to the Climatic Optimum of the Holocene (c. 8,0006,000 years BP). Judging from recent Palaeobotanical and palynological data, this period was more humid and warmer than presently, so that the tundra zone disappeared from the Eurasian continent (Fig. 11). In South Siberia a powerful expansion of the broad-leaved trees took place (Belova 1985, Volkova \& Belova 1980, Arkhipov $\&$ Volkova 1994). While in Siberia the pollen of such trees were absent in sediments dated to the periods preceding and following the Holocene climatic optimum, sediments from the optimum do contain them throughout South Siberia, from the present-day forest-steppe to the southern taiga zone (ibid.). These were, first of all, pollen of linden and elm, which were shown to occupy a continuous belt from Europe to the Far East. Oak had acquired a more restricted range (Fig. 11): in West Siberia it extended eastwards to the River Irtysh and the middle reaches of the River $\mathrm{Ob}$, and in the East it occupied the whole of Transbaikalia; in Mongolia however oak pollen has hitherto been found only in the NE part, on the River Uldz-Gol (Vipper et al. 1978). Oak pollen has been found in the upper reaches of the River Lena (Belova 1985), but we consider the oak existence there to be problematic. There are no Holocene records of oak pollen from the whole Yenisei Basin; most probably oak was disjunct in Central Siberia. 
Subsequent impoverishment of the forests began in the Far East in the Atlantic period, and in the Baikal Region and the Yenisei River basin in the Late Atlantic - Early Subboreal period. In southern West Siberia the climatic optimum began and ended later, with broad-leaved forests still flourishing in the Subboreal period (Arkhipov \& Volkova 1994). The forests of elm, linden and oak gradually disappeared from this territory during the Subboreal and Subatlantic, but the process was probably interrupted by one or two re-invasions of these trees into the western West Siberian Plain. Thus elm had disappeared from most of the plain about 2,000-3,000 years BP (Arkhipov \& Volkova 1994); oak and linden grew in the lower reaches of the River Irtysh (downstream from Tobolsk) as recently as 900 years ago (Volkova et al. 1994), while linden is still present there.

Hence during the Quaternary a continuous belt of forests with a proportion of broad-leaved trees was present at least twice: in the Pleistocene (Kazantseva Interglacial) and the Holocene (Atlantic and Subboreal). The Kazantseva Optimum (RissWürm Interglacial) was much warmer than the Holocene Optimum. Smaller expansions of broadleaved trees took place repeatedly during the Quaternary. Moreover the three interglacials under consideration (Kazantseva, Karginskii, and the Holocene) differed substantially in the degree of development of the broad-leaved forest zone. In the Kazantseva Interglacial oak had a continuous range throughout Eurasia, while linden and the elms extended north of $60^{\circ} \mathrm{N}$. In the Karginskii Interglacial the broad-leaved trees had an enormous distribution in East Siberia as far as Yakutia, but in West Siberia they occupied only the extreme south and did not extend east of the River Ob. In the Holocene, elm and linden had a continuous range not extending north of the River Angara, while the western and eastern oaks did not come into contact. So far there is no reliable evidence for the existence at latitudes $50-55^{\circ}$ of nemoral flora refuges during the most severe glaciations of the Pleistocene, at least in Siberia. Broad-leaved forests existed at those times in the Crimea, Caucasus, West Tien-Shan, and AlaiPamirs, and in North China, Korea and South Japan, but not in the Altai, Mongolia, or Transbaikalia, as earlier supposed.

\section{Materials and Methods}

This paper is based on an analysis of the ranges of Lepidoptera species considered nemoral. Data on the foodplants of these species (Table 2) were taken from numerous literature sources, most importantly Kozhantshikov (1955); Seppänen (1970); Higgins \& Riley (1970); Tshistjakov (1984); Korshunov \& Gorbunov (1995), and our own data. We inferred the species ranges first of all using the rich materials of the Siberian Zoological Museum at the Institute for Animal Systematics and Ecology, Novosibirsk (the catalogues are now available online at http://www.bionet.nsc.ru/szmn/ index.htme and http://www.geocities.com/Athens/Cyprus/ 4397/szmn/index.htm), which cover the territory of Siberia and adjacent countries. Many of these materials were collected by the first author (V. D.) during 25 years of collecting on numerous expeditions (including three joint Finnish-Russian expeditions) to many countries and regions, namely Finland, Hungary, Turkmenistan, Tajikistan, Kyrgyzstan, Kazakstan, Mongolia; and in Russia: the provinces of Nizhnii Novgorod, Saratov, Volgograd, Astrakhan, Krasnodar, Novosibirsk, Altai and Tuva Republics, the Provinces of Irkutsk, Chita, Yakutia, the Province of Magadan, the Amur Province, Primorye, the Sakhalin and Southern Kurile Islands. The second author (O. K.) collected Lepidopera for 15 years in the Crimea, Krasnodarskii Krai, Tadjikistan, Kazakhstan, the Provinces of Omsk, Novosibirsk, Kemerovo, Krasnoyarsk, Altai and Tuva Republics, the Provinces of Chita and Magadan, and South Kamchatka. Apart from the rich collections, these expeditions led us to a better understanding of the composition and existence of different faunal elements in the various environments over this vast territory. Especially fruitful in this respect were expeditions to Kemerovo Province and, most of all, to the basins of the Rivers Onon and Argun (Dubatolov \& Kosterin 1999a, b). The few gaps, mostly from outside Siberia, in our materials have been supplemented using the main literature sources on Lepidoptera of the regions considered, such as Lukhtanov \& Lukhtanov (1994) and Korshunov \& Gorbunov (1995).

The data on the distribution of nemoral Lepidoptera species were compared with equivalent data obtained by palaeobotanists, e.g. Volkova \& Belova (1980), Belova (1985), Grichuk (1989), Arkhipiv \& Volkova (1994), Fradkina (1995); the works of Nazarenko (1990, 1992), who compiled maps of the palaeovegetation of the Far East for a reconstruction of the history of the bird fauna, were also very useful. These comparisons are presented in this paper.

\section{Results}

Two categories of Lepidoptera species are here referred to as nemoral. The first comprises those with caterpillars which are mono- or oligophagous on broad-leaved (nemoral) tree species, e.g. 
Table 2. Trophical connections of Siberian and amphipalaearctic nemoral species of Lepidoptera.

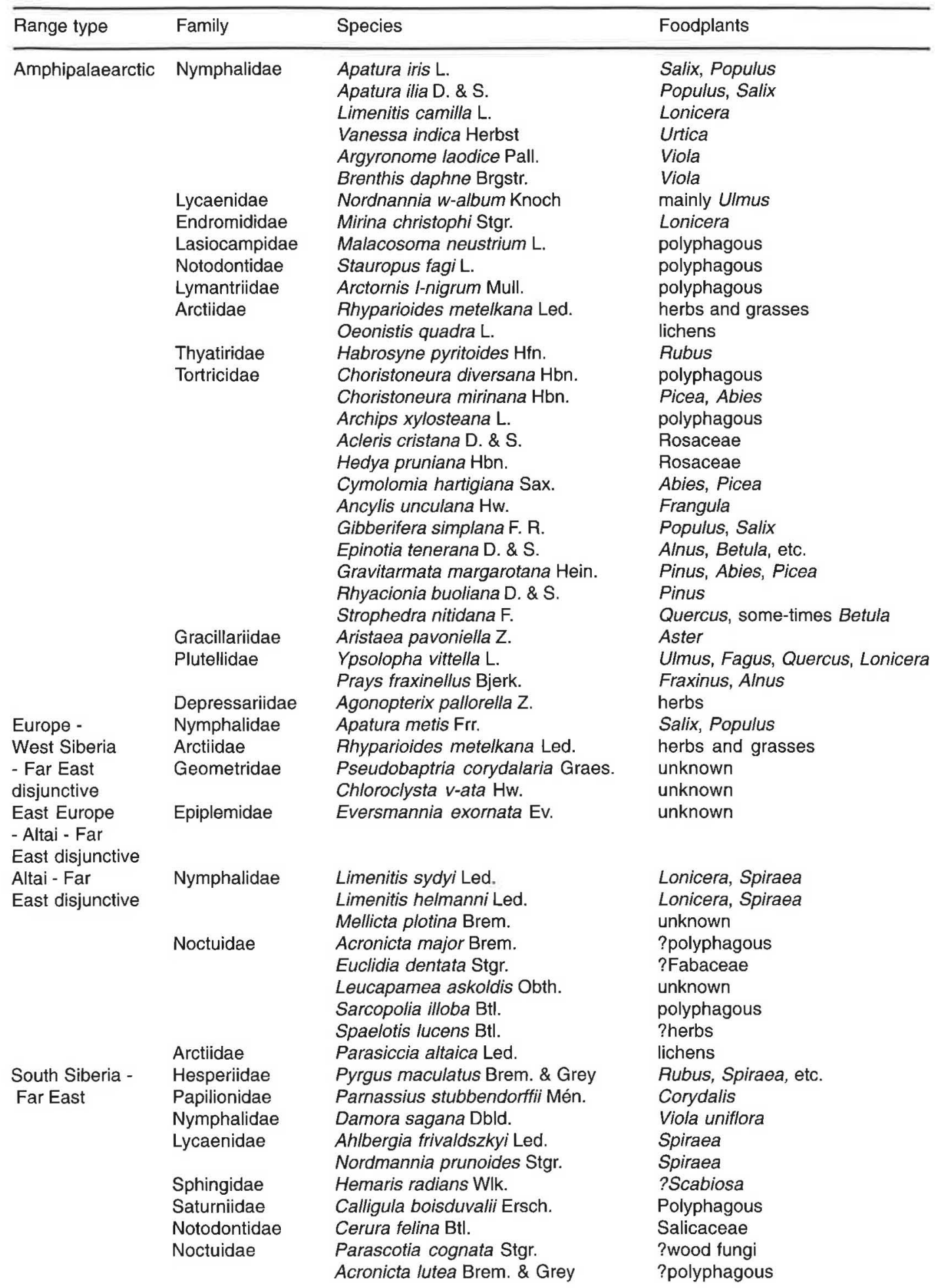




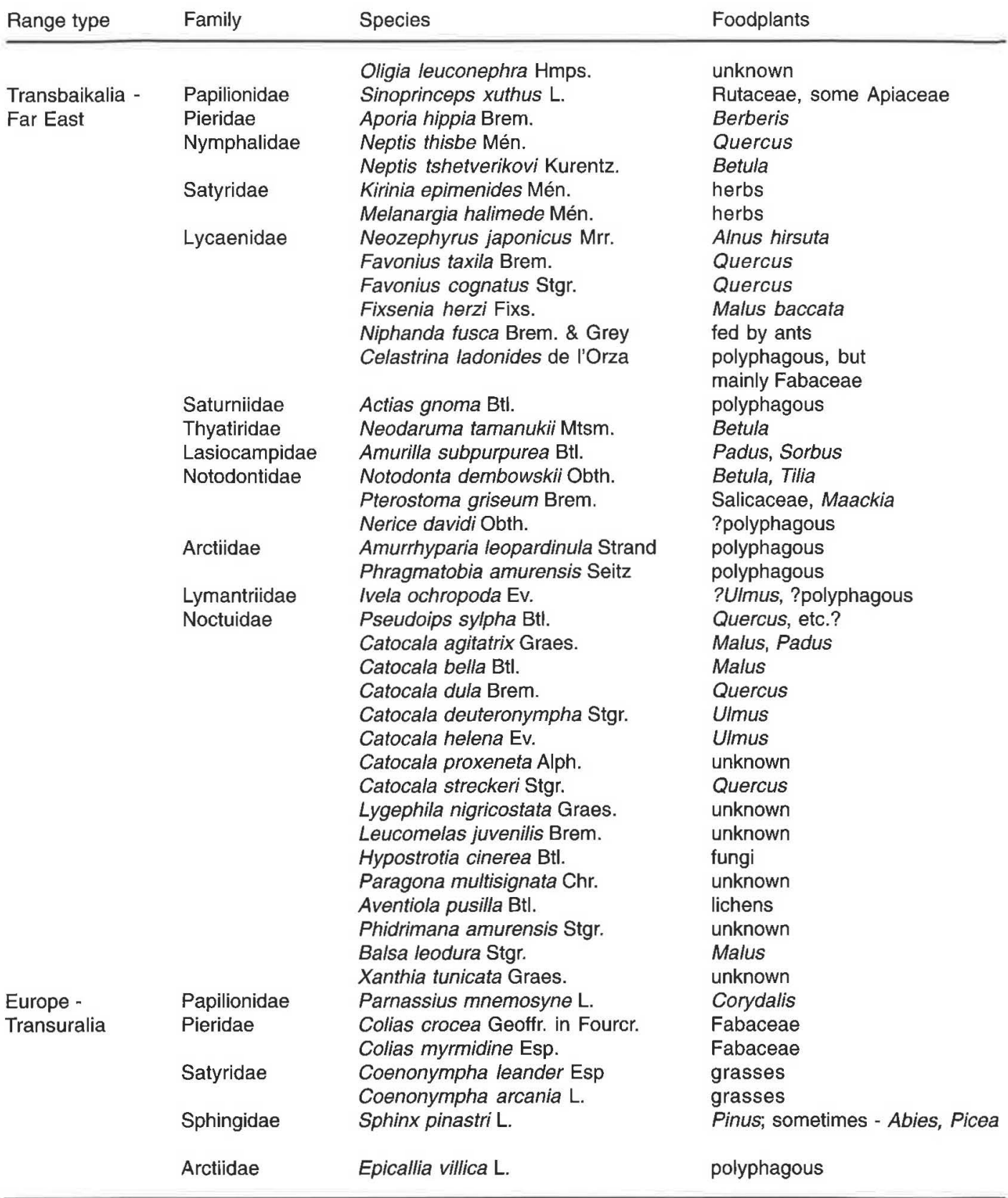

elms or oaks. Numerous species which develop only on particular broad-leaved trees can be found in Europe and East Asia. In the Siberian fauna Nordmannia w-album Knoch ${ }^{3}$ (Lycaenidae), which feeds on elm, is a good example of this group. In addition, those species should be con- sidered as nemoral in which the main part of the range lies within the zone of the broad-leaved or coniferous/broad-leaved forests where they prefer nemoral habitats (phytocenologically nemoral species).

Seven types of ranges of the Siberian nemoral

\footnotetext{
${ }^{3}$ The findings of N. w-album in West Siberia at Kurgan (Ionina, 1998) and at Isilkul, the Omsk Province (Korshunov, 1998), in our opinion, result from recent invasions of this species following artificial stands of Ulmus pumila.
} 
Lepidoptera species can be differentiated (details of the ranges outside Siberia are not considered here).

1. In some cases a species inhabits both the western and eastern, but not the central regions of the Palaearctic. This type of range is called Amphipalaearctic; it consists of two large parts, the European part (eastwards to the Urals) and the Far Eastern part (from East Transbaikalia to Japan) (Fig. 2). Well known examples are the two species of Apatura, (A. ilia D. \& S. and A. iris L.), Limenitis camilla L., Argyronome laodice Pall. (Nymphalidae), Malacosoma neustrium L. (Lasiocampidae) and Habrosyne pyritoides $\mathrm{Hfn}$. (Thyatiridae).

2. Close to the previous type is a Europe West-Siberia - Far-East disjunctive range type (Fig. 3), differing from the former by the presence of an isolated part in SE West Siberia. This type is illustrated by Apatura metis Frr. (Nymphalidae), in West Siberia inhabiting only the valley of the middle of the River Irtysh, Rhyparioides metelkana Led. (Arctiidae), occurring in the steppes of North Kulunda at the town Karasuk; and two species of Geometridae (Chloroclysta vata Hw. and Pseudobaptria corylaria Graes.), found in Siberia in the upper basin of the River $\mathrm{Ob}$.

3. An East-Europe - Altai - Far-East disjunctive range (Fig. 4) is found in one species Eversmannia exornata Ev. of the mostly tropical family Epiplemidae, inhabiting the central and eastern parts of European Russia, SE West Siberia, and the Far East (Dubatolov et al. 1994).

4. Another type of disjunct range (Dubatolov \& Zolotarenko 1996), called here the Altai - FarEast type, occurs in two areas: a smaller one in the SE part of West Siberia (including the Altai) and the main Far Eastern area (Fig. 5). Such species as Limenitis helmanni Led., L. sydyi Led. (Nymphalidae), Acronicta major Brem., Leucapamea askoldis Obth., Sarcopolia illoba Btl., Spaelotis lucens Btl. (Noctuidae), and Parasiccia altaica Led. (Arctiidae, Lithosiinae) do not inhabit the territory from the East Sayan to West Transbaikalia or, in some cases, to the Amurland; in the Far East these species are associated with broad-leaved forests. The absence of these species in Europe and the presence of their close relatives in East Asia make us suppose that they have invaded West Siberia from the Far East.

Three other types of ranges show no disjunctions:

5. A South-Siberia - Far-East range (Fig. 6), exemplified by species common in the broadleaved forests of the Far East, and also found at low altitudes in the mountains and elevations of South Siberia, from the Altai and Gornaya Shoria Mts. through the Sayan and Khamar-Daban Mts. to S Transbaikalia. They are Pyrgus maculatus Brem. \& Grey (Hesperiidae), Parnassius stubbendorffii Mén. (Papilionidae), Damora sagana Dbld. (Nymphalidae), Nordmannia prunoides Stgr., Ahlbergia frivaldszkyi Led. (Lycaenidae), Parascotia cognata Stgr., Acronicta lutea Brem. \& Grey, and Oligia leuconephra Hmps. (Noctuidae). The abundance of these species, as well as of those of the previous type, is correlated with that of nemoral plant species in this region (including lime), that will be discussed below.

Other nemoral lepidopteran species penetrate into Siberia to a small extent only, either from the East or the West:

6. The former, which show a Transbaikalia Far-East type of range, are found in the southern taiga forests of Transbaikalia (Fig. 7): Aporia hippia Brem. (Pieridae), Neptis tshetverikovi Kurentz. (Nymphalidae), Kirinia epimenides Mén., Melanargia halimede Mén. (Satyridae), Neozephyrus japonicus Mrr., Fixsenia herzi Fixs., Niphanda fusca Brem. \& Grey (Lycaenidae), Actias gnoma Btl. (Saturniidae), Hemaris radians Wlk. (Sphingidae), Neodaruma tamanukii Mtsm. (Thyatiridae), Amurilla subpurpurea Btl. (Lasiocampidae), and many Noctuidae.

7. Nemoral lepidopteran species with Europe Transuralia ranges, i.e. which penetrate from Europe into Transuralia (the western extreme of Siberia) (Fig. 8), to the Kurgan and eastern Chelyabinsk Provinces, are less numerous. Such species are Coenonympha leander Esp., C. arcania L., (Satyridae), Epicallia villica L. (Arctiidae) etc. One species, Parnassius mnemosyne L. (Papilionidae), extends as far eastward as to Tyumen and Tobolsk.

Species with Amphipalaearctic and Europe West-Siberia - Far-East disjunctive ranges are now represented by different subspecies in the West and East Palaearctic. Species with disjunctive Altai - Far-East ranges either have or have 
not formed different subspecies in the West Siberian isolates. Thus, the subspecies Limenitis helmanni helmanni Led., L. sydyi sydyi L., Acronicta major atritaigensa Dubat. \& Zolot. inhabit SE West Siberia, while L. helmanni duplicata Stgr., L. sydyi latefasciata Mén., and A. major major Brem. have their ranges in East Asia. On the other hand, West-Siberian and Far Eastern specimens of Sarcopolia illoba Btl., and Parasiccia altaica Led. cannot be distinguished.

\section{Discussion}

\subsection{Rates of divergence and timing of species formation in Lepidoptera}

We have to point out that in this work we consider ranges of species, not of genera or families. Although primitive Microlepidoptera are known as early as from the Upper Jurassic and Cretaceous, the first Macrolepidoptera are reliably known only from the Eocene-Oligocene. From the Miocene mainly extinct genera and some recent genera (Zygaena, Pontia, Aglais) exclusively represented by extinct species (one species known for each) have been recorded (Kozlov 1988). The Pliocene Lepidoptera are poorly known, but palaeontologists assume that the first recent species appeared in this period (Sukhacheva 1980). The palaeontological record of the recent lepidopteran species begin in the Pleistocene, e.g. Achillides $\mathrm{cf}$. maackii Men. (Papilionidae) from Japan, Aglia tau L. (Saturniidae) from Finland, Belenois crawshayi Btl. (Pieridae) and Pseudonaclia puella Bsd. (Syntomidae) from Zanzibar (Kozlov 1988). Thus, the formation of the recent species of the higher Lepidoptera, a relatively young group of insects, should be attributed to the late Pliocene or, more probably, to the Pleistocene. For this reason we consider the latter period as the most important for the interpretation of the recent species ranges, while an analysis of earlier epochs would be necessary for understanding the recent ranges of taxa of higher rank, such as genera and families.

The importance of the Pleistocene as the period of formation of many recent species is supported by the local lepidopteran faunas of the highlands of Southern Europe and Asia. There are a number of closely related but different species from many families, which inhabit different mountain systems (e.g. the Alps and the Pyrenees) or different parts of the same mountain systems (e.g. different ranges of the Tien-Shan or AlaiPamir Mts.). There is no doubt that their divergence occurred during the Pleistocene when cryophylic insect species existed at low altitudes during glacials, so that mountain systems could exchange with these species, and were isolated in highlands during interstadials, which allowed allopatric speciation.

There are many species pairs separated by more ancient barriers, for instance pairs of boreal species of Lepidoptera, associated with the forest zone, inhabiting Asia and North America. They were territorially separated several million years ago (Mikkola et al. 1991). However, the real period of speciation in such species pairs may be much shorter. The longevity of species should not be confused with the time it takes for species to form. It was shown that palaeontological data mostly fit the so-called punctuated equilibrium model, which implies that time of species formation is as a rule much shorter than periods of species existence without noticeable changes (stasis) (Gould \& Eldredge 1977). Longevity of static plant and animal species may attain 7-10 million of years (Stanley 1982).

For univoltine species, even 100,000 years may be sufficient for species divergence attaining species rank, at least for Lepidoptera monophagous on oak (see section 4.2). Five endemic species of the genus Omiodes Gn. (=Hedylepta Led.) (Pyraustidae: Pyraloidea), trophically restricted to bananas, seem to have arisen on the Hawaiian Islands after bananas were introduced there by man about a thousand years ago (Zimmerman 1960). In this case several thousand generations appeared to be sufficient for speciation (Omiodes produces several broods a year).

Taking into account speciation rates, and repeated large-scale perturbations of the climate and zonality in the temperate zones during the Pleistocene, it can be concluded that, for a historical analysis of the distribution of recent nemoral lepidopteran species, the most decisive events were those of the Late Pleistocene and Holocene. 
The same opinion was expressed by Golovach (1984), when analysing the ranges of the Diplopoda of the European part of the former USSR.

\subsection{An attempt to reconstruct the history of the nemoral Lepidoptera fauna of Siberia}

In the first half of the Pliocene there existed a continuous belt of mixed broad-leaved/coniferous forests of a Turgai type in Eurasia (Baranov 1959, cited in Matyushkin 1982). This provided conditions for a wide transpalaearctic distribution of lepidopteran species dependent on the broadleaved (nemoral) forests. Since the broad-leaved tree species still extended as far north-east as to the Chukotka Peninsula, there existed a possibility for exchange of nemoral species between Eurasia and North America. It disappeared in the Late Pliocene, due to considerably cooler climate, when in the Chukotka Peninsula the earliest tundra plant communities developed in Eurasia (Fradkina 1995). The Beringian land 'bridge' between Asia and North America lasted until the late Miocene. In the Pliocene there was a strait between the continents. However, a narrow strait does allow exchange of strongly flying Lepidoptera. A good example here can be the near identity, at a subspecies level, of the lepidopteran faunas associated with the shrub tundra on both sides of the present Bering Strait (Mikkola et al. 1991). In our opinion, the time since the last Beringian land connection in the Pleistocene (ca. 10000 years ago) would suffice for subspecific differentiation, provided that no migration took place. In the Early Pliocene both sides of the Bering Strait were covered with broad-leaved forests, which in our opinion was a pre-requisite for exchange between the nemoral components of their lepidoptera faunas and an obstacle for specific differentiation of Asian and American populations of nemoral Lepidoptera.

At present there are characteristic nemoral genera of Lepidoptera common to North America and Eurasia, e.g.: Apoda Haw. (=Cochlidion Hbn.) and Latoia Guer. (=Parasa Moore) (Limacodidae), Paramidea Kusn. (Pieridae), Habrosyne Hbn. (Thyatiridae), Oreta Wlk. (Drepanidae), Epiplema H.-S. (Epiplemidae), Malacosoma Hbn. (Lasiocampidae), Saturnia Hbn., Antheraea Hbn. and Actias Leach (Saturniidae), Sphecodina
Blanch. and Proserpinus Hbn. (Sphingidae), Peridea Steph. and Nerice Wlk. (Notodontidae), Idia Hbn., Hypenodes Dbld., Dysgonia Hbn., Mocis Hbn., Plusiodonta Gn., Eudocima Billb., Hypocala Gn., Pangrapta Hbn., Araeopteron Hmps., Eutelia Hbn., Raphia Hbn., Phlogophora Tr., Chytonix Grt., Condica Wlk., Balsa Wlk. and some others (Noctuidae). We excluded from this list genera like Agrius Hbn. (Sphingidae) and Utetheisa Hbn. (Arctiidae), which are well-known migrants and capable of crossing oceans, and also genera which inhabit boreal (taiga) forests. All the genera listed are represented by different species on different sides of the Pacific. On the other hand, there are a number of species which have Amphipalaearctic ranges in Eurasia (3 species of Apatura F., Limenitis camilla L., Argyronome laodice Pall., Malacosoma neustereustria L., and Habrosyne pyritoides Hfn.), these species being represented on both sides of the continent by only slightly different subspecies. No doubt the contacts between the nemoral faunas of both sides of Eurasia were more recent than those between Eurasia and North America.

The history of the Eopleistocene, Pleistocene, and Holocene is a series of glaciations interrupted by warm interglacials (Table 1). During these epochs the distribution of the broad-leaved tree species and the corresponding nemoral faunas changed cyclically: they repeatedly retreated to southern refuges and were restored during interglacials, sometimes as a continuous transpalaearctic belt. These processes were reconstructed for the birds of the East Palaearctic by Nazarenko $(1982,1992)$, who, however, did not notice clear differences between the glacial cycles either in severity of the climatic deteriorations or the degree of amelioration of interglacials. But he pointed out that the resolution of the historical-biogeographical method when reconstructing faunistic events of the past "is limited in its effective use to the 2-3 most recent glacial-interglacial cycles, i.e. at most to the upper and middle parts of the Middle Pleistocene" (Nazarenko 1982, 1992).

To illustrate this as for nemoral Lepidoptera, let us analyse the fauna trophically dependent on oak. As noted above, the latest continuous Transpalaearctic range of oak was established in the Kazantseva (Riss-Würm) Interglacial, about 130,000-100,000 years BP. Presently no Lepi- 
doptera species strictly monophagous on oak has an Amphipalaearctic range. The only oak-eating Amphipalaearctic species, Strophedra nitidana F. (Tortricidae) (Danilevskii \& Kuznetsov 1968), can under some conditions develop on the birch (Kennel 1921). Other oak monophages are represented by at least sibling species on the western and eastern sides of Eurasia, e.g. Spatalia argentina D. \& S. and S. doerriesi Graes. (Notodontidae), Catocala sponsa L. and C. dula Brem. (Noctuidae), and Ancylis mitterbacheriana D. \& S. and A. nemorana Kuzn. (Tortricidae). These monophages on oak are monovoltine and have undergone about 100,000 generations since the Kazantseva Interglacial. This seems quite sufficient for speciation in view of the tempo of species divergence in Lepidoptera discussed above.

Sibling species, whose divergence can more or less be attributed to isolation since the Kazantseva (Riss-Würm) Interglacial, can also be found among Lepidoptera feeding on elm (Dicranura ulmi D. \& S. and D. tsvetajevi Schintlm. \& Svir.), and also among those feeding on some smallleaved trees, shrubs and herbs.

The double Zyryanka (Valdai or Würm) Glacial, which succeeded the Kazantseva Interglacial, was most severe (Arkhipov \& Volkova 1994), although its ice-sheets occupied less area than during the previous Samarov (Dnieper or Riss) Glacial. The broad-leaved forests shrank to small refuges in the extreme south of Europe, on the South Crimea, the Caucasus, the mountains of Central Asia, and the southern half of East Asia (Fig. 10). These regions retained a nemoral lepidopteran fauna.

After deglaciation, the last occurrence of a continuous belt of forests with broad-leaved trees was in the Middle Holocene. These were not polydominant broad-leaved forests, but rather forests of the southern taiga type which included linden, elm and in some regions oak as subdominants. The same tree species grew in the forest-steppe zone (V. S. Volkova, pers. comm). This provided conditions for a wide transpalaearctic distribution of some lepidopteran nemoral species.

Those forests obviously contained species which presently inhabit the northernmost forests with broad-leaved trees and other elements of the nemoral flora within the southern taiga zone of the European part of Russia and the southern Far
East. The closest analogue of the Siberian forests with broad-leaved trees of the Middle Holocene are, in our opinion, the southern taiga forests of eastern Transbaikalia, which include up to three species of elm (Ulmus) and the Mongolian oak (Quercus mongolica Fischer ex Ledeb.), and which have a Lepidoptera fauna enriched with Far East nemoral species showing Siberian ranges of type 6, i.e. not found elsewhere in Siberia. However, the forests of the Holocene Climatic Optimum should have contained more nemoral plant and animal species; for example, the fauna connected with walnut (Juglans mandshurica Maxim.) should have had a wider range, as this tree reached the Khamar-Daban Mts. on the southern Baikal coast (Belova 1985). In West Siberia the remains of the Holocene Optimum communities are found at Tyumen and Tobolsk, where elm and linden survived up to the present while the butterfly fauna contains such nemoral species as Parnassius mnemosyne L. (Papilionidae) and Apatura iris L. (Nymphalidae).

Analysing the distribution of the nemoral lepidopteran species we can conclude that a considerable part of these species at present have ranges of the Amphipalaearctic, Europe - West-Siberia Far-East and Altai - Far-East disjunctive type (Fig. 2-5); these species are exemplified in Table. 2. By their trophic links almost all the nemoral lepidopteran species in Siberia are either polyphagous or develop on poplars, willows, honey-suckles, some Rosaceae, fir, spruce, or on some herbs (Table 2). Only a few of them are monophagous on Ulmus (Table 2). This means that these species, except for the elm-eating ones, are nemoral only in a climatic or cenotic rather than a trophic sense. Their foodplants are widely distributed throughout South Siberia.

Those species which exhibit a continuous South-Siberia - Far-East range (Fig. 6) are common in the broad-leaved forests of the Far East and in Siberia in the 'lime island' of the upland of Gornaya Shoria and in the chernevaya taiga of the Altai, Kuznetskii Alatau, Sayan, and KhamarDaban Mts., which retain many nemoral plant species (Krylov 1891, Kuminova 1957, 1960, 1963, Ogureeva 1980, Teplyakova 1988, Polozhii \& Krapivkina 1985, Epova 1956, 1961, Ermakov 1998, Kamelin 1998). We date the nemoral refuges in these Siberian regions to after the 
beginning of the Holocene, as supposed by Reverdatto (1940), in contrast to the authors mentioned above, who considered them to be preglacial. The existence of the main of refuges was conditioned by a combination of relatively low latitude and moderate elevation of NW margins of the Altai-Sayan mountain system, which at present provide the maximum precipitation in Siberia (up to $1500 / y r$ in the western foothills of the Kuznetskii Alatau Mts.) and a deep snow cover preventing the ground from freezing (Polozhii \& Krapivkina 1985).

As a result of isolation following the last breakup of a continuous Central Siberian belt of the broad-leaved forests including elm and linden, no more than 6,000-7,000 years after the Climatic Optimum of the Holocene, the West Siberian and Far Eastern populations of the nemoral Lepidoptera with disjunctive West-Siberia - Far-East ranges differentiated into separate subspecies (e.g., Limenitis helmanni helmanni, L. sydyi sydyi, and Acronicta major atritaigensa in SE West Siberia, versus $L$. helmanni duplicata, $L$. sydyi latefasci$a t a$, and $A$. major major in the Far East). Butterflies with Amphipalaearctic and Europe - WestSiberia - Far-East ranges (e.g. three species of Apatura, Limenitis camilla, and Nordmannia $w$-album), are represented by poorly differentiated subspecies in the West and East, probably of the same age. Only mobile species like those of the Lepidoptera were able to expand their ranges in the Holocene Climatic Optimum and became transpalaearctic. No species of the much less mobile Diplopoda managed to establish an Amphipalaearctic range (Golovach 1984). They failed to reach Europe from East Asia or vice versa.

The majority of Siberian nemoral species most probably have an eastern origin. Amphipalaearctic species of the genera Apatura and Limenitis, and also those with disjunctive Altai - Far-East ranges (Limenitis helmanni Led., L. sydyi Led.,
Parasiccia altaica Led., Acronicta major Brem., and Sarcopolia illoba Bt1.) have at present a much wider distribution in East Asia than in the European or Siberian parts of their range. Some of them (Apatura and Limenitis species), as well as some species with continuous South-Siberia - Far East ranges (e.g., Ahlbergia frivaldszkyi Led., and Nordmannia prunoides Stgr.) have their closest relatives in the fauna of East Asia. During the Holocene Climatic Optimum an active westward migration of the East Asian species probably took place $^{4}$. Since this period was rather short, only a few species managed to reach Europe to form Amphipalaearctic ranges later (Table 2). An interesting case is the range of Eversmannia exornata Ev., the only European representative of the tropical/subtropical family Epiplemidae (sometimes combined with Uraniidae). Its main range lies in the Far East, but it inhabits also SE West Siberia and the central and eastern parts of European Russia (Fig. 4) (Dubatolov et al. 1994). Its closest relatives occur in southern China, Nepal and India (Inoue 1982, 1998 ${ }^{5}$ ).

Most probably the so-called 'Baikal Corridor' or 'South-Siberian Corridor in the Lake Baikal area', through which, as suggested by Mikkola (1987, 1988) and Matyushkin (1982), animal species migrated in post-glacial times and which is believed to have been situated south of Lake Baikal, was in fact much wider, and for the nemoral species occupied a territory north to $60^{\circ}$, in which the forests with broad-leaved trees ranged in the Holocene Optimum. The migration of boreal species could take place further to the north, since most territory of Siberia north to the River Yana, now covered with larch forests and foresttundra, was in the Atlantic period occupied by dark-needle forests with spruce and fir (Neischtadt 1957, Khotinskii 1977).

The eastwards migrations of species from Europe cannot be traced in the nemoral higher Lepi-

\footnotetext{
${ }^{4}$ Here an East Asian origin of these species implies that they came to the West Palaearctic from East Asia in the Holocene. Their very origin could be quite different. Probably they had become extinct in Europe during glaciations and then expanded from refuges in East Palaearctic.

5 "Epiplema" fuscifrons Wrr., depicted in the cited work (pl. 138, f. 4), is similar to Eversmannia exornata Ev. both by wing pattern and the structure of the signa of the female bursa and should be transferred to the genus Eversmannia Chr. It is noteworthy that there are no close species in the Russian Far East or Japan. Morphological differences between the Japanese/Amur species, attributed to the genus Epiplema H.-S. and Eversmannia exornata are very profound, no less than of a tribal or subfamily rank. The study of the nominotypical species of the genus Epiplema is necessary for a decisive solution of the generic attribution of all these species.
} 
doptera. Only species of the southern taiga were able to penetrate eastwards, for e.g. Lemonia dumi L. to the Amurland (Streltzov et al. 1997). Some characteristic species of the European broadleaved forests reach the Urals (e.g. Pararge aegeria L. (Satyridae), Callimorpha dominula L. and Euplagia quadripunctaria Poda (Arctiidae)) or Transuralia (e.g. Parnassius mnemosyne L. (Papilionidae), Coenonympha leander Esp. and C. arcania L. (Satyridae), Epicallia villica L. (Arctiidae)). Two additional probably thermophic species, which demonstrate a preference to the nemoral forest-steppe in Europe, Iphiclides podalirius L. (Papilionidae) and Mellicta aurelia Nick. (Nymphalidae), reach the West Altai through birch groves within the steppe zone. Anyway, such European-Transuralian species are much less numerous than the Transbaikalian-Far Eastern ones, listed in the first section of the paper and in Table 2.

The putative absence of eastward migrations of nemoral Lepidoptera can most probably be explained by the fact that the maximum of expansion of the broad-leaved trees in the eastern parts of Eurasia took place earlier than in West Siberia. In the Far East it happened in the Boreal period, in East Siberia in the Atlantic period, and in West Siberia in the Early Subboreal period. In the early Subboreal period such forests were already beginning to be depleted in the East. In the Late Atlantic - Early Subboreal periods the European nemoral lepidopteran species could be widely distributed over southern West Siberia, but the subsequent depletion of the forests with broad-leaved trees forced them to retreat, leaving outposts only in the NW extremity of West Siberia.

Nazarenko (1992) came to similar conclusions concerning the prevailing directions of expansion of the nemoral birds of the East Palaearctic. We should like to paraphrase the outstanding botanist Kleopov (1990): "If we consider that in all the coenocomplexes of the forest-steppe of Europe ... East Asian and, in part, North American genetic relations are quite well expressed, one cannot deny the tremendous role of the genetic centres of the Holarctic adjacent to the Pacific in the process of the formation of the recent flora of Europe. These centres, especially the East Asian ones, beginning in the middle Tertiary Pe- riod, repeatedly sent migrational waves of various historico-coenological elements to Europe". Our analysis shows that this is true for the nemoral species of Lepidoptera as well.

\section{Conclusions}

1. During the Quaternary interglacials, including the Holocene, a continuous belt of forests with broad-leaved (nemoral) trees occured at least twice in Eurasia: in the Kazantseva (RissWürm) Interglacials of the Pleistocene and in the Atlantic and Subboreal periods of the Holocene. At that time conditions existed for a wide transpalaearctic distribution by latitudinal migrations of lepidopteran nemoral species. The Kazantseva Interglacial was warmer than the Holocene Climatic Optimum, and this was the last time when oak, together with the fauna connected with it, had a continuous transpalaearctic range.

2. The period after the Kazantseva Optimum (about 100,000 years) seems to have been sufficient for species-rank divergence of isolated populations of Lepidoptera.

3 . Hitherto there is no real evidence of the existence, at least not in Siberia, of refuges of nemoral flora and fauna at latitudes $50-55^{\circ} \mathrm{N}$ during the last, most severe, glaciations of the Pleistocene. In those periods the broad-leaved forests and their corresponding fauna had retreated to the Crimea, the Caucasus, lakes Aral and Balkhash, the Tien-Shan Mts., Central and South China, Korea, and South Japan, but were not preserved in the Altai or Transbaikalia, as thought earlier. However, the existence of a northern refuge of some broad-leaved trees and the corresponding fauna in the foothills of the southern Urals cannot be excluded.

4. During the Holocene Climatic Optimum a transpalaearctic or nearly transpalaearctic range was most probably acquired by nemoral lepidopteran species connected with Ulmus or with non-broad-leaved deciduous trees (birch, aspen, willows), shrubs and herbs, i.e. mostly by cenotically nemoral species.

5. During the Holocene Climatic Optimum a westward migration of the nemoral Lepidop- 
tera fauna took place from the eastern parts of the Palaearctic; some species reached Western Europe (Apatura species and Limenitis camilla, etc.), one species (Eversmannia exornata) reached Eastern Europe, a number of species (Limenitis helmanni, L. sydyi, Acronicta major, etc.) the south-east of W Siberia, and many species (Niphanda fusca, Catocala dula, etc.) Transbaikalia. An opposite migration was probably prevented by the fact that the Holocene optimum of broad-leaved forests occurred earlier in East Siberia than in West Siberia.

6. We suggest that the formation of the recent disjunctive (Amphipalaearctic, Europe - WestSiberia - Far-East and Altai - Far-East) species ranges resulted from the depletion in Central Siberia of the broad-leaved forests in the Holocene Subboreal period rather that in the Late Pliocene-Early Pleistocene, as assumed earlier. The refuges of the nemoral and subnemoral flora of south-eastern West Siberia and southern Central Siberia (the 'lime island', 'chernevaya taiga' of the Altai, Sayan and Khamar-Daban Mts.) probably date to the Holocene Climatic Optimum. This is why these territories have no endemic nemoral species, at least not of Lepidoptera.

7. The modern species ranges of Lepidoptera were formed by rather recent landscape changes in the Holocene.

Acknowledgements. The authors express their sincere gratitude to Prof. V. S. Volkova (Novosibirsk, Russia) for most useful consultations and help with literature, to Prof. M. G. Sergeev, Dr. D. V. Logunov, Dr. O. G. Berezina (Novosibirsk, Russia) and Dr. E. A. Belyaev (Vladivostok, Russia) for fruitful discussions; to Dr. V. S. Vasilenko for information on some Geometridae, to Prof. V. N. Dubatolov and Dr. Y. A. Dubatolova, Dr. V. I. Krasnov for valuable consultations, to Prof. Y. S. Ravkin (Novosibirsk, Russia) for help with literature, to Dr. H. Yoshimoto (Tokyo, Japan) for information on hostplants of some East Asian Lepidoptera species. We are very grateful to Dr. K. Mikkola and Dr. Ann Forsten (Helsinki, Finland) for critically reading our manuscript and kindly making numerous valuable comments and language corrections; and to Dr. G. H. Harper (Edinburgh, United Kingdom) for a final linguistic revision. Our special thanks go to Mr. V. A. Brinikh, Director of the Daurskii State Nature Reserve, whose energy brought to reality the expeditions to the low River Argun basin in 1996 and 1997.

\section{References}

Anufriev, G. A. 1979: Eurasian amphiboreal ranges of cicadids (Homoptera, Auchenorryncha) as a reflection of general stages of genesis of European and Far Eastern fauna. (In Russian). - VII International Symposium of Entomofauna of Central Europe, Materials: 127-129. Nauka Press, Leningrad.

Arkhipov, S. A. \& Volkova, V. S. 1994: Geological History, Pleistocene Landscapes and Climate in West Siberia. (In Russian). - [United Institute of Geology, Geophysycs and Mineralogy, SB RAS, Proceedings] 823. 105 pp. Nauka Press, Novosibirsk.

Arkhipov, S. A. \& Votakh, M. R. 1973: The history of vegetation in the Middle-Late Würm and Holocene in the upper Ob' River valley. (In Russian). - - In: Saks, V. N. (ed.) [Pleistocene of the Siberia and Adjacent Regions. For the IX Congress of INQUA, New Zealand, 1973]: 130-143. Nauka Press, Moscow.

Bakhareva, V. A. 1985: Palynological characteristics of the Upper Quaternary and Holocene sediments at the village Pershino on Irtysh. (In Russian). - In: Volkova, V. S. \& Khlonova A. F. (eds), [Palynostratigraphy of the Mesosoic and Cenosoic of Siberia]: 115-120. Nauka Press, Novosibirsk.

Baranov, V. I. 1959: Stages of Flora and Vegetation Development in the Tertiary on the USSR Territory. 364 pp. (In Russian). Vysshaya Shkola Press, Moscow.

Belova, V. A. 1985: Vegetation and Climate of the Late Cenozoic of the southern Eastern Siberia. 158 pp. (In Russian). Nauka Press, Novosibirsk.

Belyshev, B. F. \& Haritonov, A. Y. 1978: On latitude and longitude disjunctions in the Eurasian dragonflies (Odonata, Insecta) and their origin. (In Russian with English summary). - Izvestiya Sibirskogo otdeleniya Akademii Nauk SSSR. Seriya biologicheskikh nauk 1978(5): 114 188.

Belyshev, B. F. \& Haritonov, A. Y. 1981: Geography of Odonata of Boreal Faunistic Kingdom. - 297 pp. (In Russian). Nauka Press, Novosibirsk.

Bespalyi, V. G. 1984: Main problems of Pleistocene glaciations in North-East Asia. (In Russian). - In: Bespalyi, V. G. (ed.), [Pleistocene Glaciations of the East Asia]: 3-16. North-East Complex Scientific Research Institute FESC AS USSR Press, Magadan.

Bezrukova, E. V. 1996: Vegetation and Climate of the Baikal Area in the Late Glaciation and Holocene. $\mathrm{Ph}$. D. Thesis, United Institute of Geology, Geophysics and Mineralogy (Novosibirsk). - 22 pp. (In Russian). Irkutsk

Boyarskaya, T. D. \& Malaeva, E. M. 1967: Vegetation Development in Siberia and Far East in the Quaternary. - 202 pp. (In Russian). Nauka Press, Moscow.

Danilevsky, A. S. \& Kuznetsov, V. I. 1968: Leaf rollers Tortricidae, tribe Laspeyresiini. (In Russian). - Fauna of the USSR, new series, No 98, 5(1). 636 pp. Nauka Press, Leningrad.

Dubatolov, V. V., Antonova, E. M. \& Kosterin, O. E. 1994: Eversmannia exornata (Eversmann, 1837), the only known representative of the Epiplemidae family (Lepidoptera) in West Palaearctic. - Actias, Russian Jour- 
nal for Scientific Lepidopterology (Moscow) 1(1-2): 19-23.

Dubatolov, V. V. \& Kosterin, O. E. 1999a: Butterflies (Lepidoptera, Hesperioidea, Papilionoidea) of the Dauria International Nature Reserve. (In Russian with English summary). - Dubatolov, V. V. (ed.), [Insects of Dahuria and neighbouring territories] II: 138-194. Novosibirsk.

Dubatolov, V. V. \& Kosterin, O. E. 1999b: Butterflies (Lepidoptera, Hesperioidea, Papilionoidea) of the Argun' Basin. (In Russian with English summary). - Dubatolov, V. V. (ed.), [Insects of Dahuria and neighbouring territories] II: 195-221. Novosibirsk.

Dubatolov, V. V. \& Zolotarenko, G. S. [1996] 1995: New taxa of Acronictinae (Lepidoptera, Noctuidae) from the mountains of South Siberia. - Actias, Russian Journal for Scientific Lepidopterology (Moscow) 2(1-2): 33-36.

Epova, N. A. 1956: Relics of broad-leaf forests in a fir taiga of the Khamar-Daban. (In Russian). — [Biological-Geographical Scientific Research Institute at Irkutsk State University, Proc.], 16(1-4): 25-61.

Epova, N. A. 1961: On a chacteristic of a fir taiga of the Khamar-Daban. (In Russian). - [Buryat Complex Research Institute SB AS USSR, Proc.] 4: 121-129.

Ermakov, N. 1998: The Altaian relict subnemoral forest belt and the vegetation of pre-Pleistocene mountainous landscapes. - Phytocenologia 28: 31-34.

Esjunin, S. L., Golovach, S. I. \& Penev, L. D. 1993: The fauna and zoogeography of spiders inhabiting oak forests of the East European Plain. - Ber. nat.-med. Verein Innsbruck 80: 175-249.

Eskov, K. Y. 1984: Continental drift and problems of historical biogeography. (In Russian). - In: Chernov, Y. I. (ed.), [Faunogenesis and Phylocenogenesis]: 24-92. Nauka Press, Moscow.

Florov, D. N. 1955: Origin (genesis) of the taiga entomofauna. (In Russian), — Zool. Zh. 34(4): 789-799.

Fradkina, A. F. 1995: Palynostratigraphy of Paleogene and Neogene sediments of North-Eastern Russia. $-82 \mathrm{pp}$. (In Russian). United Institute of Geology, Geophysics and Mileralogy Press, Novosibirsk.

Golovach, S. I. 1984: Distribution and faunogenesis of Diplopoda in the European part of the USSR. (In Russian) - In: Chernov, Y. I. (ed.), [Faunogenesis and Phylocenogenesis]: 92-138. Nauka Press, Moscow.

Golubeva, L. V. 1978: Vegetation of Northem Mongolia in the Pleistocene and Holocene (the Selenga and Orkhon River basins). (In Russian). - Izvestiya Akademii nauk SSSR, Seriya geologicheskaya 3: 68-81.

Gorbunov, P. Y. \& Olschwang, V. N. 1991: An attempt of cenotic approach to protection of regional taxonomical diversity of insects (on an example of butterflies of the Urals). (In Russian). - In Il'yashenko, V. Y. \& Mazin, L. N. (eds), [Studying of Rare Animals in RSFSR (Materials for Red Book)]: 15-23. Central Scientific Research Laboratory of Hunting Enterprise and Nature Reserves Press, Moscow.

Gorodkov, K. B. 1979: Faunistical connections between Siberia and Central Europe. (In Russian). - VII Intersational Symposium of Entomofaunistics of Middle Europe, Materials: 30-33. Nauka Press, Leningrad.
Gorchakovskii, P. L. 1968: Plants of European Broadleaf Forests on the eastern borders of their ranges. (In Russian). - [Institute of Ecology of Plants and Animals UB AS USSR, Proc.] 59: 208 pp. UB AS USSR Press, Sverdlovsk.

Gould, S. J. \& Eldredge, N. 1977: Punctuated equilibria: the tempo and mode of evolution reconsidered. - Paleobiology 3: 115-151.

Grichuk, V. P. 1989: History of flora and vegetation of Russian plain in the Pleistocene. - 184 pp. (in Russian). Nauka Press, Moscow.

Grosvald, M. G. 1989: The Last Great Glaciation of the USSR territory. (In Russian) [New in the Live, Science, Engineering. Series "Earth Sciences". - 48 pp. Znanie Press, Moscow.

Higgins, L. G. \& Riley, N. D. 1970: A Field Guide to the Butterflies of Britain and Europe 381 pp., 60 pl. Collins, London.

Inoue, H. 1982: Epiplemidae. - In: of H. Inoue, S. Sugi, H. Kuroko, S. Moriuti and A. Kawabe, Moths of Japan 1: 575-579. Kodansha, Tokyo.

Inoue, H. 1998: Uraniidae from Nepal. - Haruta, T. (ed.) Moths of Nepal 5. Tinea 15, Suppl. 1: 81-83, pl. 138.

Ionina, N. G. 1998: [Spacial and temporal dynamics of Lycaenidae (Lepidoptera) communities of the Southern Transuralia. - Ph. D. Thesis, All-Russian Scientific Research Institute of Veterinarian Entomology and Arachnology. 21 pp. (In Russian). Tyumen.

Kennel, J. 1921: Die palaearktischen Tortriciden, Zoologica 21(54): 547-742. Stuttgart.

Kamelin, R. V. 1998: Materials on the history of the flora of Asia (the Altaian mountain country). - $240 \mathrm{pp}$. (In Russian). Altai State University Press, Barnaul.

Khlonov, Y. P. 1965: Lime and Lime Forests in West Siberia. - 156 pp. Nauka Press, Novosibirsk.

Khotinskii, N. A. 1977: Holocene of North Eurasia. - 192 pp. (In Russian). Nauka Press, Moscow.

Kleopov, Y. D. 1990: Analysis of the Flora of Broad-leaf Forests of the European Part of the USSR. - 352 pp. (In Russian). Naukova Dumka Press, Kiev.

Kononenko, V. S. \& Mikkola, K. 1992: Zoogeography of the autumn and spring fauna of the Noctuidae of the Palaearctic arboreal zone. - SEL VIII Congress Helsinki 1992. Abstracts: 13. Helsinki.

Korobeinikov, Y. I., Olschwang, V. N. \& Erokhin, N. G. 1990: Geographical analysis of entomofauna of the mountain forests of the South Urals with respect to the history of its development. (In Russian). - In: Smirnov, N. G., Bolshakov, V. N., Kosintsev, P. A., Panova, N. K., Korobeinikov, Y. I., Olschwang, V. N., Erokhin, N. G. \& Bykova, G. V. Historical Ecology of Animals in Mountains of the South Urals: 45-67. UB AS USSR Press, Sverdlovsk.

Korshunov, Yu. P. 1998: New descriptions and adjustments to the book "Butterflies of Asian part of Russia”. - 71 pp. (In Russian). Novosibirsk.

Korshunov, Yu. \& Gorbunov, P. 1995: Butterflies of Asian Part of Russia. A Guide. - 202 pp. (In Russian). Ekaterinburg.

Kosterin, O. E. 1987: Discovery of East-Asiatic dragonfly (Odonata, Libellulidae) at the Mangerock lake (Altay). (In Russian). - In: Tsherepanov, A. I. (ed.), 
[Insects, mites and helmints]: 57-63. Nauka Press, Siberian Department, Novosibirsk. [Series: New and little known species of the fauna of Siberia 19]

Kozhantshikov, I. V. 1955: Order Lepidoptera. (In Russian). - In: Pavlovskii, E. N. \& Shtakelberg, A. A. (eds.), [Forest Pests. A handbook]: 35-285. AS USSR Press, Moscow-Leninrad.

Kozhevnikov, Y. P. \& Ukraintseva, V. V. 1992: Some features of vegetation cover of Eurasia in the earliest Holocene. (In Russian). - Bot. Zh. 77(8): 1-9.

Kozlov, M. V. 1988: Paleontology of Lepidoptera and the problems of phylogeny of the order Papilionida. (In Russian). - In: Ponomarenko, A. G. (ed.), [Cretaceous Biocenotic Crisis and Insect Evolution]: 16-69. Nauka Press, Moscow.

Krasnoborov, I. M. 1992: Family 46. Fagaceae; family 47. Ulmaceae. (In Russian). — In: Krasnoborov, I. M. \& Malyshev, L. I. (eds.) Flora Sibirea 5: Salicaceae - Amaranthaceae: 70-76, 235-236. Nauka Press, Novosibirsk.

Krishtofovich, A. N. 1958: An Origin of the Flora of the Angarian Land.] (n Russian). - In: Sukachev V. N. (ed.), [Materials on a history of flora and vegetation of the USSR] 3: 7-41. AS USSR Press, Moscow-Leningrad.

Krylov, P. N. 1891: Lime in the Piedmonts of Kuznetskii Alatau. -40 pp. (In Russian). Tomsk University Press, Tomsk.

Kuminova, A. V. 1951: On the modern state of the lime forest in the Kuznetskii Alatau. (In Russian). -- [Proc. Tomsk Univ.] 116: 181-186.

Kuminova, A. V. 1957: Teletsky refugium of the Tertiary vegetation. (In Russian). - [Eastern Branch of the USSR Academy of Sciences, Proc.] 2: 104-108.

Kuminova, A. V. 1960: [Vegetation Cover of the Altai.] 450 pp. (In Russian). Nauka Press, Novosibirsk.

Kuminova, A. V. 1963: Some questions of formation of the modern Altai vegetation. (In Russian). - In: Sukachev, V. N. (ed.), [Materials on a history of flora and vegetation of the USSR] 4: 438-461. AS USSR Press, Moscow-Leningrad.

KurbatSKII, V. I. 1988. Genus 6. Malus. (In Russian), In: Polozhii, A. V. \& Malyshev, L. I. (eds), Flora Sibirea 8: Rosaceae: 25. Nauka Press, Novosibirsk.

de Lattin, G. 1967: Grundriss der Zoogeographie. 602 pp. Gustav Fischer Verlag, Jena.

Logunov, D. V. 1996: Preliminary report on the EuroSiberian faunal connections of jumping spiders (Araneae, Salticidae). - Acta Zoologica Fennica 201: 71-76.

Lukhtanov, V. \& Lukhtanov A. 1994: Die Tagfalter Nordwestasiens, Herbipoliana, Buchreihe zur Lepidopterologie 3: $440 \mathrm{~S}$.

Matveeva, O. V. 1968: History of Vegetation of the Antropogene of Mountain Regions of the Southern West Siberia, Piedmonts of the Altai and the Yenisei Depression Based on Palynological Data. - Ph. D. Thesis, Geological Institute. 27 pp. (In Russian). Moscow.

Matyushkin, E. N. 1976: European - East-Asian break between the ranges of terrestrial vertebrates. (In Russian). - Zool. Zh. 55(9): 1277-1291.

Matyushkin, E. N. 1982: Regional differentiation of the Palaearctic forest fauna in the past and at present. (In
Russian), - In: Sokolov, I. A. (ed.), [Theoretic and Applied Aspects of Biogeography]: 59-80. Nauka Press, Moscow.

Menitskii, Y. L. 1982: Cospectus specierum generis Quercus L. Gerontogeae. (In Russian). - [Komarov's Readings] XXXII: 60 pp. Nauka Press, Leningrad.

Mikkola, K. 1987: Patter of noctuid species common between the extremities of the Palaearctic zone: a result of glacial and postglacial movements. - Tinea suppl. 12: 310-315.

Mikkola, K. 1988: The subarctic and boreal components of the noctuid communities of the southern Siberia mountains, as indicators of postglacial movements of noctuid faunas (Lepidoptera, Noctuidae). Report No. 3 from the joint Soviet-Finnish entomological expeditions to Siberia. (In Russian and English). - In: Zlobin, V. V. (ed.), The connections between entomofauna of the North Europe and Siberia: 95-111. ZIN AS USSR Press, Leningrad.

Mikkola, K., Lafontaine, J. D. \& Kononenko, V. S. 1991: Zoogeography of the Holarctic species of the Noctuidae (Lepidoptera): importance of the Beringian refuge. Entomologica Fennica 2: 157-173.

Nazarenko, A. A. 1982: On faunistic cycles (extinction - expansion - extinction...) with special reference to the East Palaearctic dendrophilous avifauna. (In Russian). - Zh. Obshchei Biologii, 6: 823-835.

Nazarenko, A. A. 1990: Recent history of the East Palaearctic avifauna: transzonal interchange of the forest elements between South and North Asia since the last 35.000 years. - Intern. 100-th Aniv. DOG Meeting, Proc. Bonn, 1988: 81-87. Bonn.

Nazarenko, A. A. 1992: Faunistical Cycles: Extinction - Expansion - Extinction... A Mordern History of the Dendrophilous Omitofauna of Eastern Palaearctic. - Sc. D. Thesis, Institute of Biology and Pedology, 51 pp. (In Russian). Vladivostok.

Neischtadt, M. I. 1957: History of Forests and Paleogeography of the USSR in Holocene. - 404 pp. (In Russia). AS USSR Press, Moscow,

Ogureeva, G. N. 1980: Botanical Geography of the Altai. 188 p. (In Russian). Nauka Press, Moscow.

Peshkova, G. A. 1984: On the accordance in development of mesophilous and xerophilous florae of the Baikalian Siberia in the Cenozoic. (In Russian). - In: Malyshev, L. I. (ed.), [The History of Vegetation Cover of North Asia]: 144-156. Nauka Press, Novosibirsk.

Polozhii, A. V. \& Krapivkina, E. D. 1985: Relics of the Tertiary Broad-leaved Forests in the Flora of Siberia. - 158 pp. (In Russian). Tomsk Univ. Press, Tomsk.

Reverdatto, V. V. 1940: Main aspects of development of the post-Tertiary flora of Central Siberia. - Sovetskaya Botanika 2: 48-64.

Rougeot, P. C. 1983: Die Nachtfalter Europas und Nordafrikas. - In: Ulrich Roesler, R. (ed.), I. Schwärmer und Spinner. Teil 1. Bombycoidea: Endromidae, Lasiocampidae, Lemoniidae, Attacidae (=Saturniidae), Brahmaeidae, Notodontoidea: Notodontidae, Dilobidae, Thaumetopoeidae, Sphingidae, Ctenuchidae. 281 pp., 40 t. Verlag Erich Bauer, Keltern.

Rusanov, B. S. 1967: History of formation of the modern (Quatemary) land surface of Eastern Yakutia. (In Rus- 
sian). - In: Rusanov, B. S., Borodenkova, Z. F., Goncharov, V. F., Grinenko, O. V. \& Lazarev, P. A. [Geomorphology of Eastern Yakutia]: 303-356. Yakutsk Book Press, Yakutsk.

Seppänen, E. J. 1970: Suurperhostoukkien ravintokasvit. 179 pp. Helsinki.

Shilova, G. N. 1981: Palynological Characteristics of the Sediments and the History of Vegetation Development of the Late Cenozoic of the Mongolian People's Republic. - Ph. D. Thesis, Institute of Geology and Geophysics (Novosibirsk). 27 pp. (in Russian). Moscow.

Stanley, S. M. 1982: Macroevolution and the fossil record. - Evolution 36: 460-473.

Stegmann, B. 1938: Gründzuge der ornitogeographischen Gliederung des Paläarktischen Gebietes. (In Russian with German summary), - Faune de l'URSS. 1(2): Oiseaux. 157 pp. Éd. acad. sci. URSS, Moscou-Leningrad.

Shumilova, L. V. 1962: Botanical Geography of Siberia. 437 pp. (In Russian). Tomsk University Press, Tomsk.

Smimov, N. G., Bolshakov, V. N., Kosintsev, P. A., Panova, N. K., Korobeinikov, Y. I., Olschwang, V. N., Erokhin, N. G. \& Bykova, G. V. 1990: Historical Ecology of Animals in the Mountains of the South Urals. - 245 pp. (in Russian). UB AS USSR Press, Sverdlovsk.

Streltzov, A. N., Malikova, E. L. \& Tshistjakov, Yu. A. 1997: First record of the family Lemoniidae (Lepidoptera) from the Russian Far East. - Far Eastem Entomologist, 51: 8-9.

Sukacheva, I. D. 1980: Order Papilionida. Lepidoptera. (In Russian). - In: Roddendorf, B. B. \& Rasnitsyn, A. P. (eds), [Historical development of the class Insecta], [Paleontological Institute AS USSR, Proc.] 175: 110-112. Nauka Press, Moscow.

Teplyakova, T. E. 1988: Nemoral Floristic Complex of the Altai. (In Russian). - In: [II Youth Conference of Botanics of Leningrad, Proc.], (a manuscript deposited in the All-Russian Institute of Scientific and Technical Information, No 5682-B88).

Tshistjakov, Y. A. 1984: Distribution of higher moths of the superfamilies Bombycoidea, Notodontoidea and some Noctuoidea in main forest formations of South Primorie. (In Russian). - In: [Fauna and Ecology of Invertebrates of the Far East (Pests and Entomophags)]: 80-99. FESC AS USSR Press, Vladivostok.

Ukraintseva, V. V. 1988: Flora, Vegetation and Natural
Conditions in Siberia in the Late Antropogene. Sc. D. Thesis, Institute of botany. 48 pp. (In Russian). Kiev.

Ukraintseva, V. V. 1996: Late Pleistocene and Holocene floras of Siberia. (In Russian). - Bot. Zh. 81(12): $37-48$.

Velichko, A. A. (ed) 1993. Evolution of landscapes and climates of the Northern Eurasia: 1-103, maps 1-8. (In Russian). Nauka Press, Moscow.

Vereshchagin, V. N. \& Mironova, L. V. (eds) 1982: Stratigraphic dictionary of the USSR, Paleogene, Neogene, Quaternary. - 616 pp. (In Russian). Nauka Press, Leningrad.

Vipper, P. B, Dorofeyuk, N. I., Meteltseva, E. P. \& Sokolovskaya, V. T1978: History of vegetation development in Northern Mongolia in the Holocene. (In Russian). - In: Bannikova, I. A. \& Medvedev, L. N. (eds), [Geography and Dynamics of Plant and Animal World of MPR.] - Lavrenko, E. M. \& Sokolov, V. E (eds) [Biological Resources and Nature Conditions of Mongolian People's Republic] 10: 19-24. Nauka Press Moscow.

Volkov, I. A., Gurtovaya, E. S., Firsov, L. V., Panychev, V. A. \& Orlova, L. A. 1973: Structure, age, and formation history of a Holocene peatery near the village Gorno-Slinkino on Irtysh. (In Russian). - In: Saks, V. N. (ed.), [Pleistocene of Siberia and Neighbouring Regions. For the IX Congress of INQUA, New Zealand, 1973]: 34-39. Nauka Press, Moscow.

Volkova, V. S. \& Belova, V. A. 1980: On a role of broadleaved trees in vegetation of the Holocene in Siberia. (In Russian). - In: Saks, V. N. (Ñàêñ, Â. Í.) (ed.), [Paleopalynology of Siberia. Papers of the Soviet Palynologists to the V International Conference on Palynology (Cambridge, England, 1980)]: 112-117. Nauka Press, Moscow.

Zimmerman, E. S. 1960: Possible evidence of rapid evolution in Hawaian moths. - Evolution 14(1): 137-138.

Zolotarenko, G. S. 1981: Main stages of evolution of Macrolepidoptera as exemplified by Siberian fauna. (In Russian). - In: Tsherepanov, A. I. (ed.), [Fauna and ecology of Arthropoda of Siberia. Materials of V Conference of entomologists of Siberia]: 44-50. Nauka Press, Novosibirsk.

Zolotarenko, G. S. 1994: Ecologo-geographial aspects of cutworm fauna formation in Siberia. - Siberian Journal of Ecology 1(6): 527-534. 


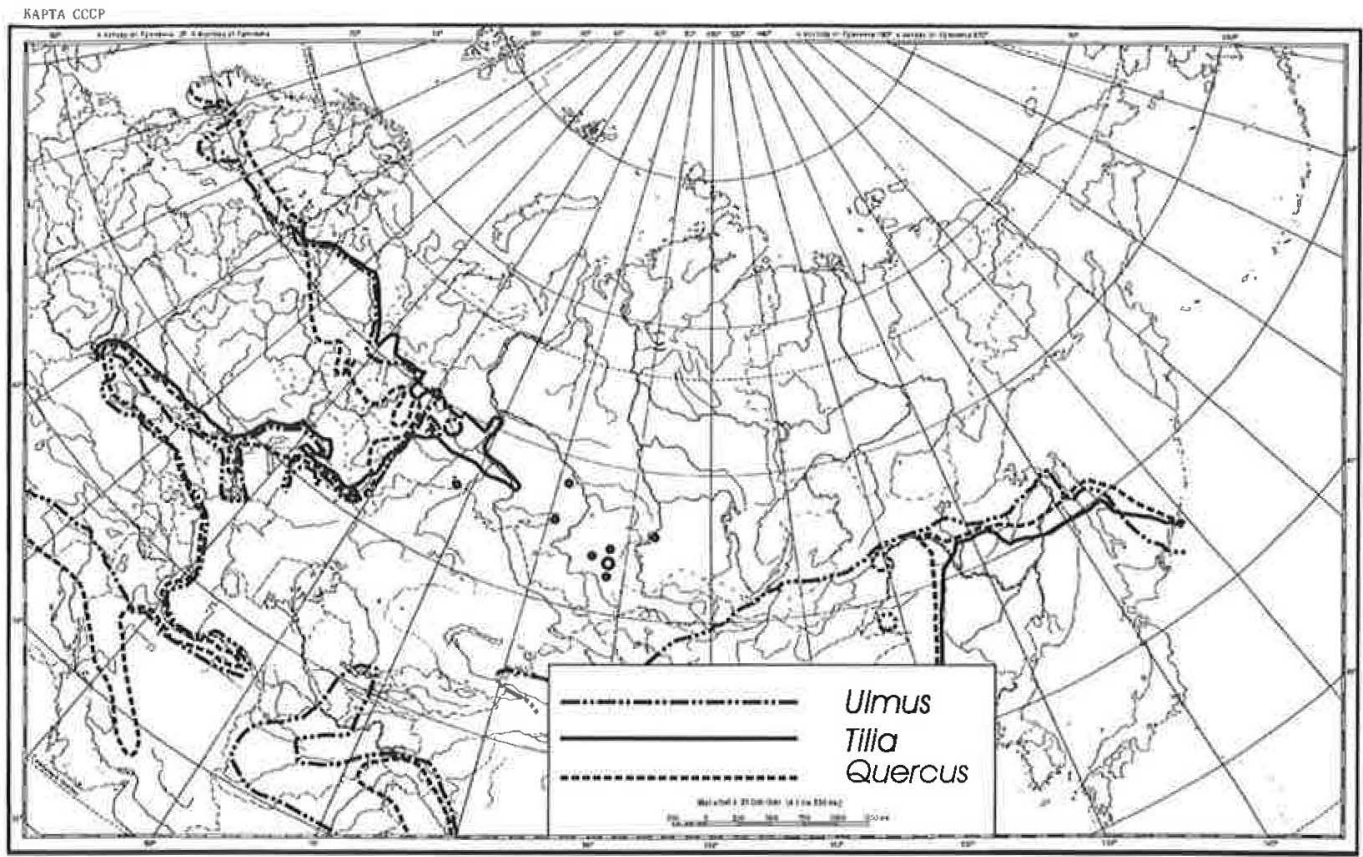

Fig. 1. Ranges of the broad-leaved tree genera present in Siberia (according to Khlonov, 1965; Gorchakovskii, 1968; Polozhii, Krapivkina, 1985; Krasnoborov, 1992, Velichko, 1993, and others).

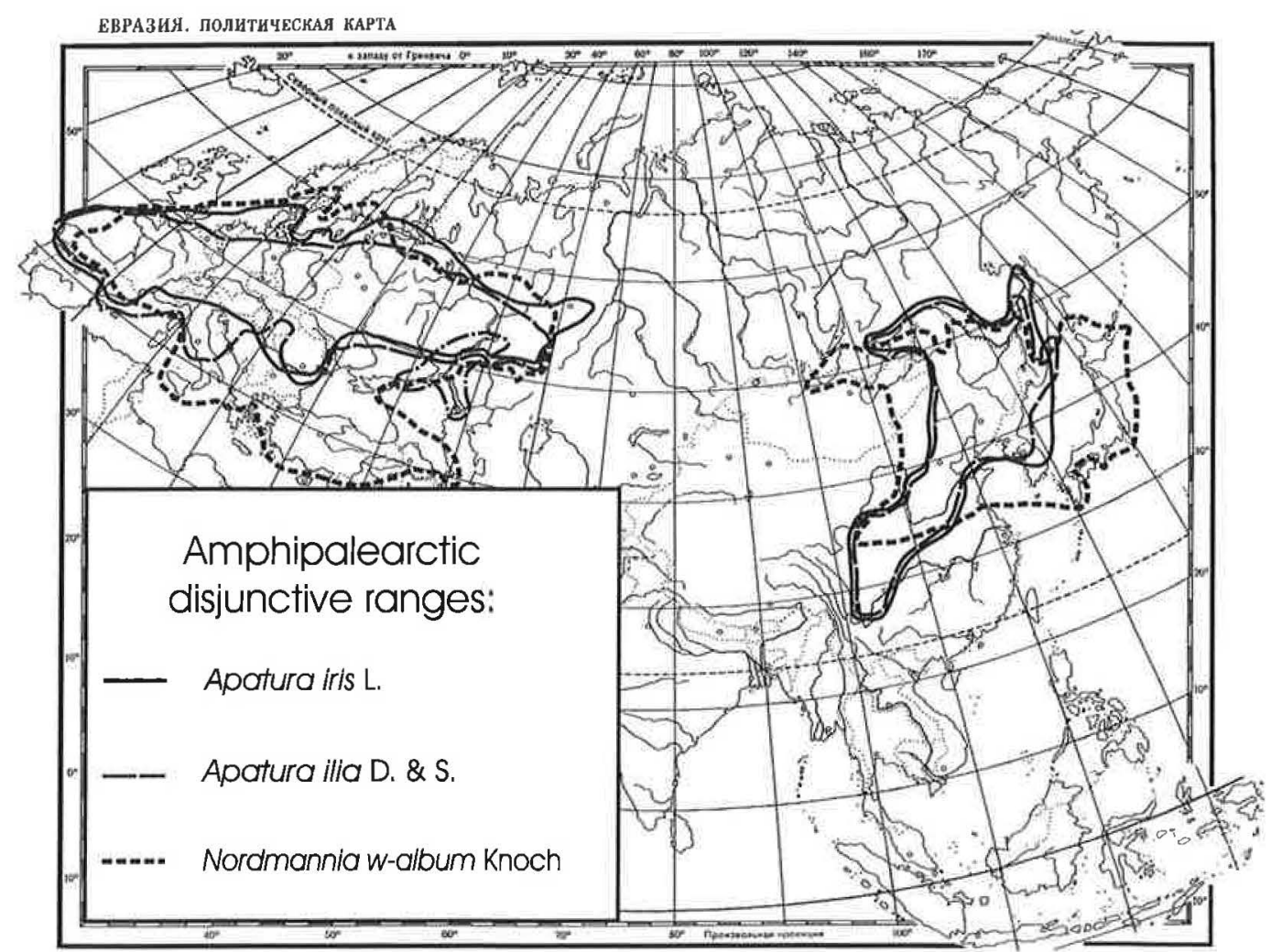

Fig. 2. Examples of the Amphipalaearctic disjunctive ranges. 


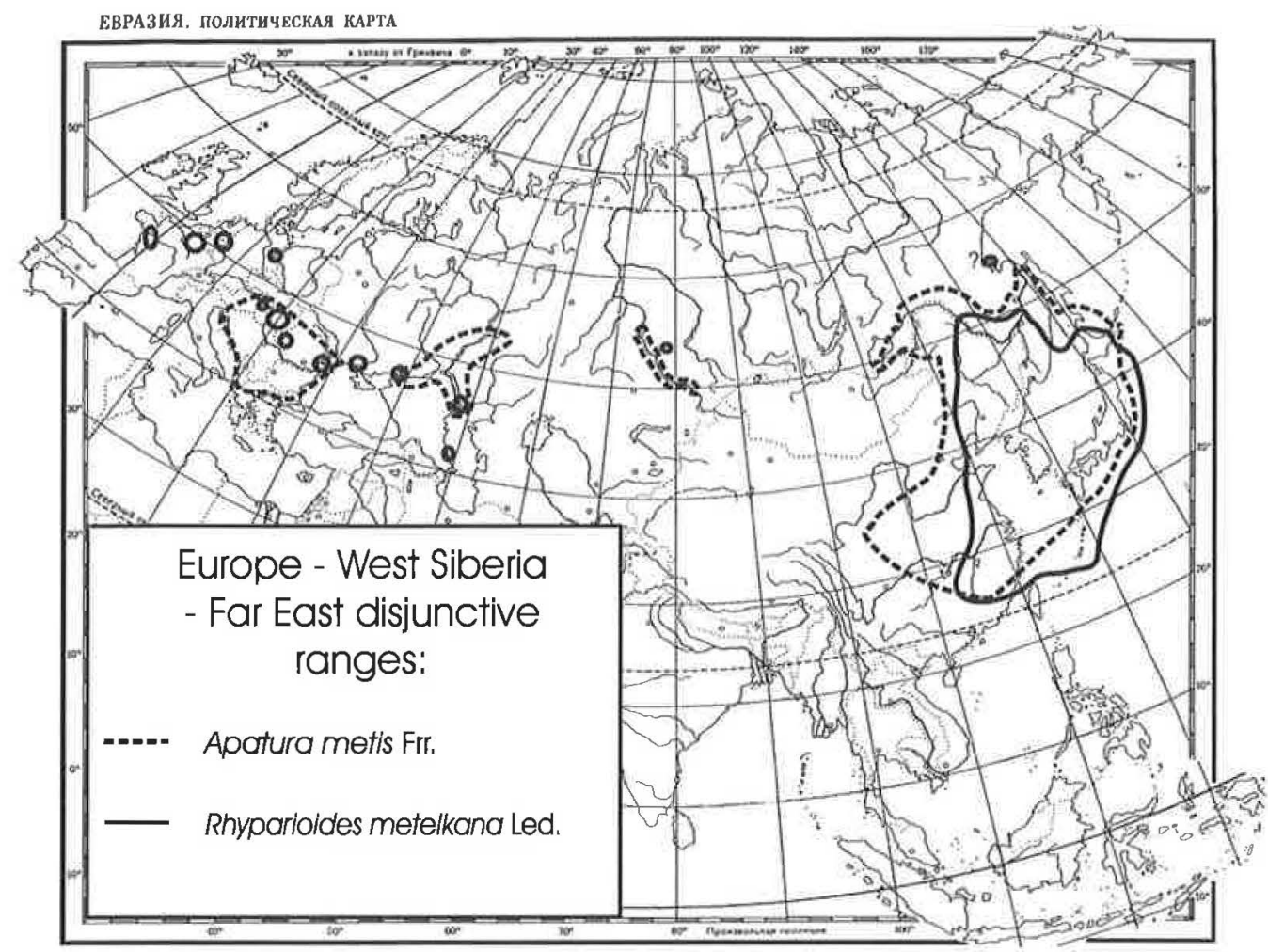

Fig. 3. Examples of Europe - West Siberia - Far East disjunctive ranges.

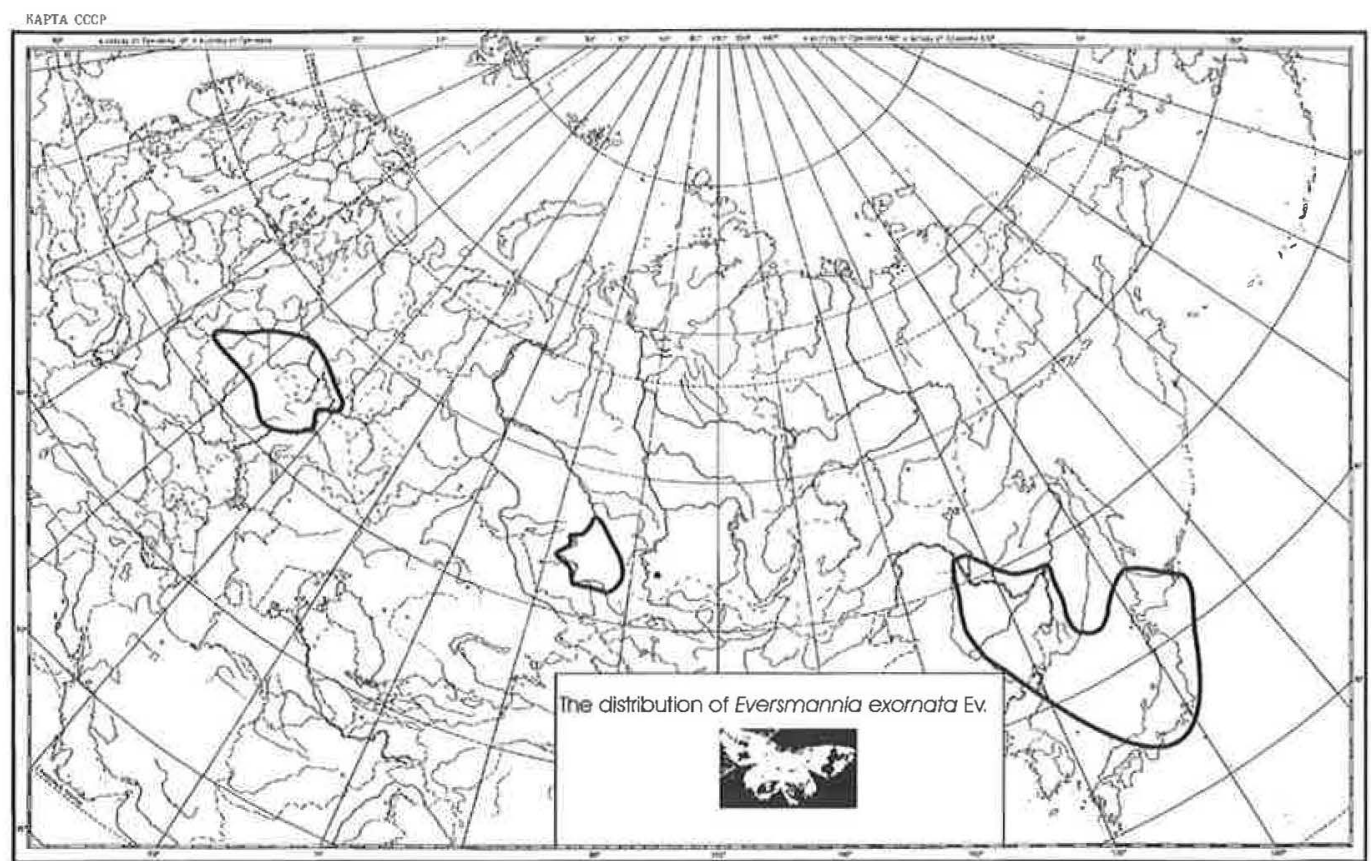

Fig. 4. The distribution of Eversmannia exornata Ev. (Epiplemidae) (East European - Altai - Far East disjunctive range). 


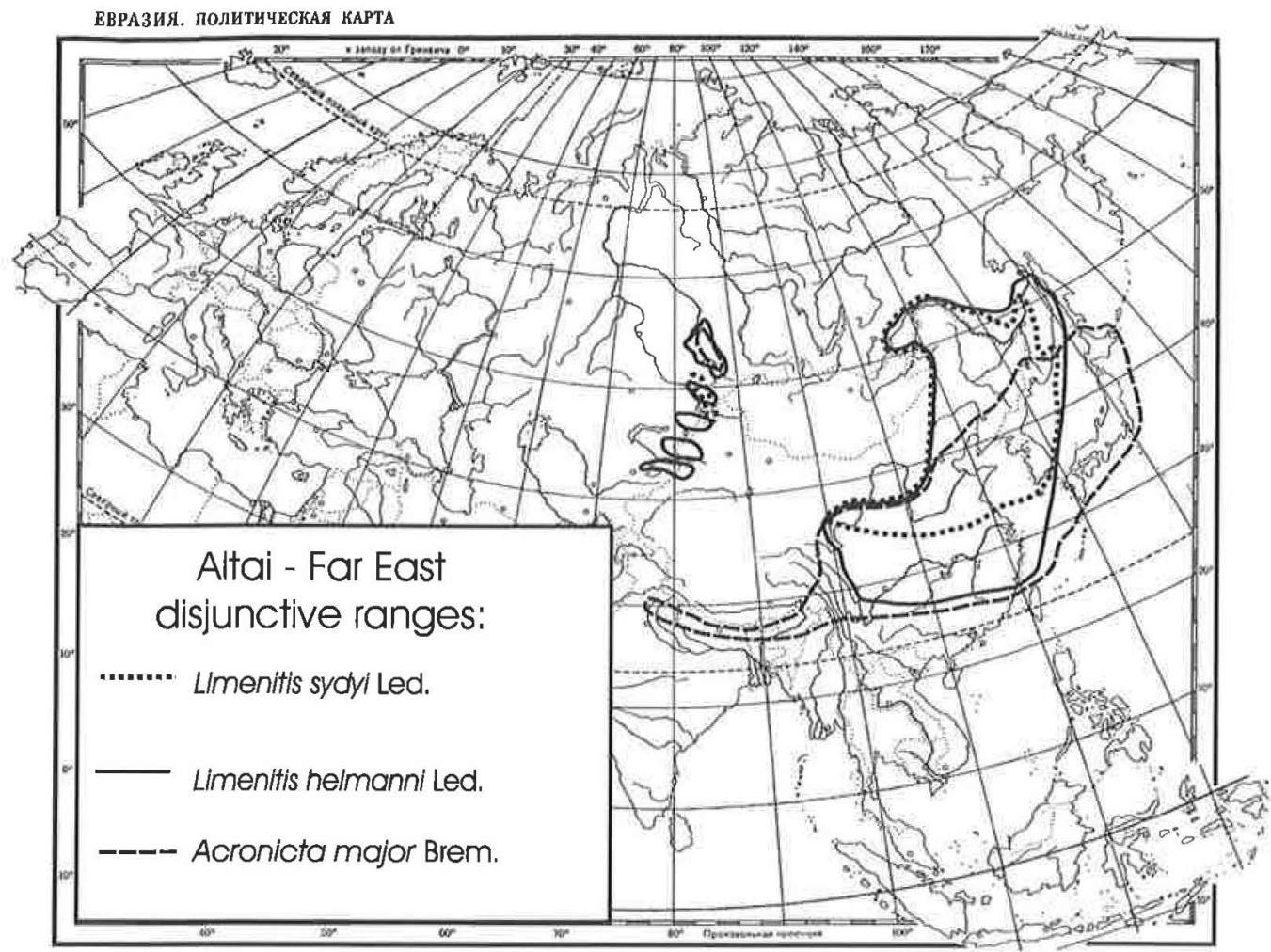

Fig. 5. Examples of Altai - Far East disjunctive ranges.

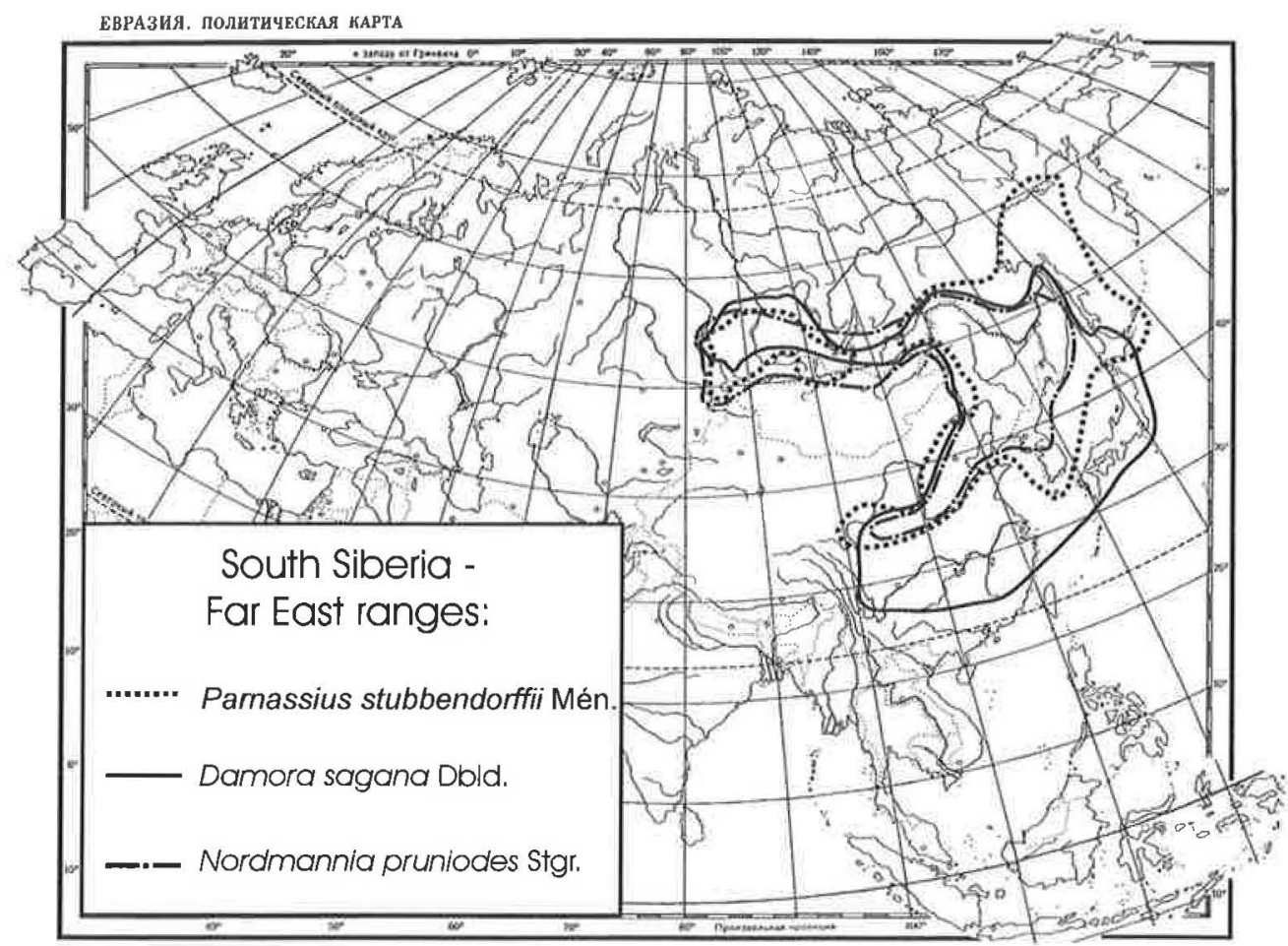

Fig. 6. Examples of South Siberia - Far East ranges. 


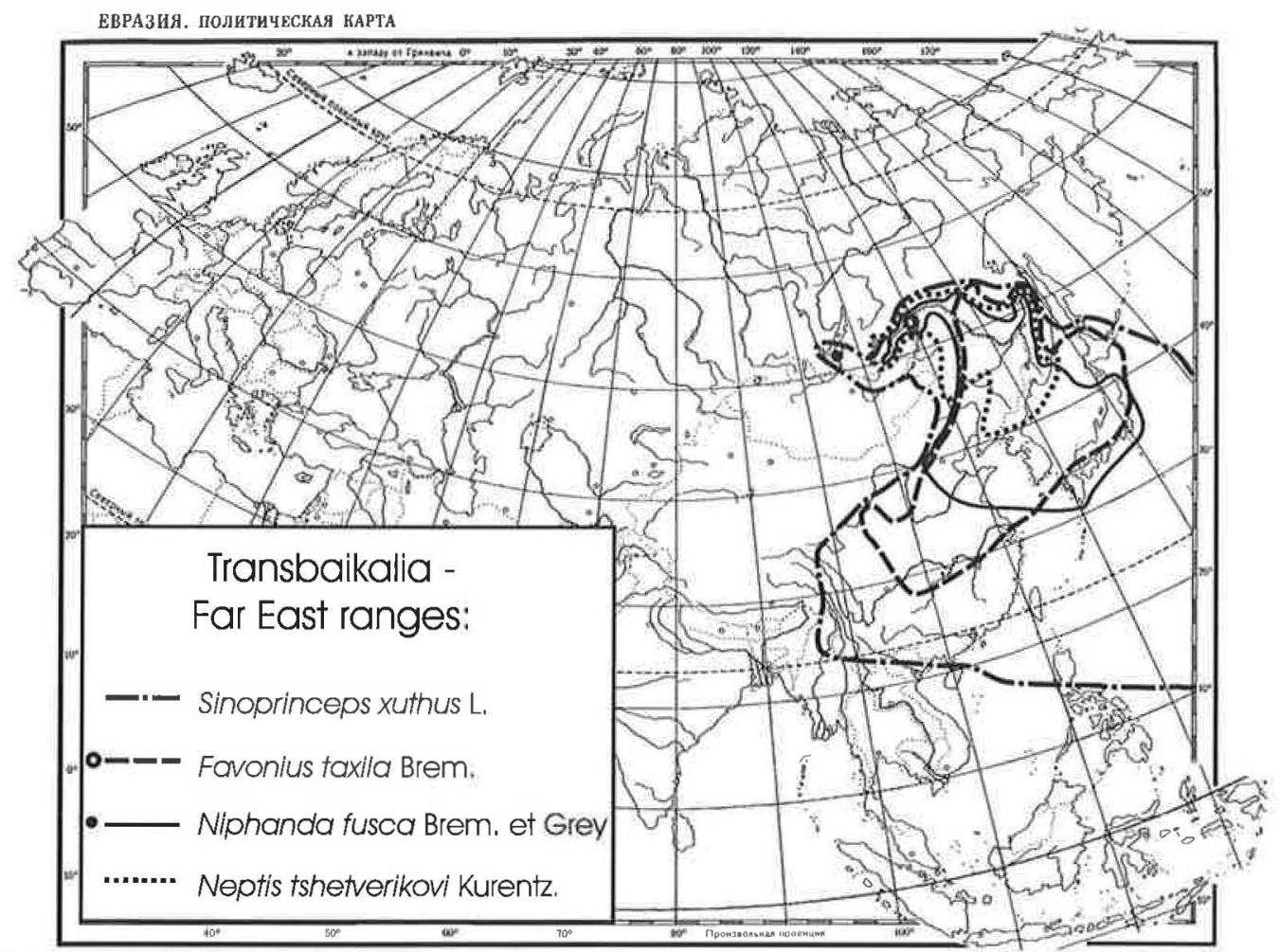

Fig. 7. Examples of Transbaikalia - Far East ranges.

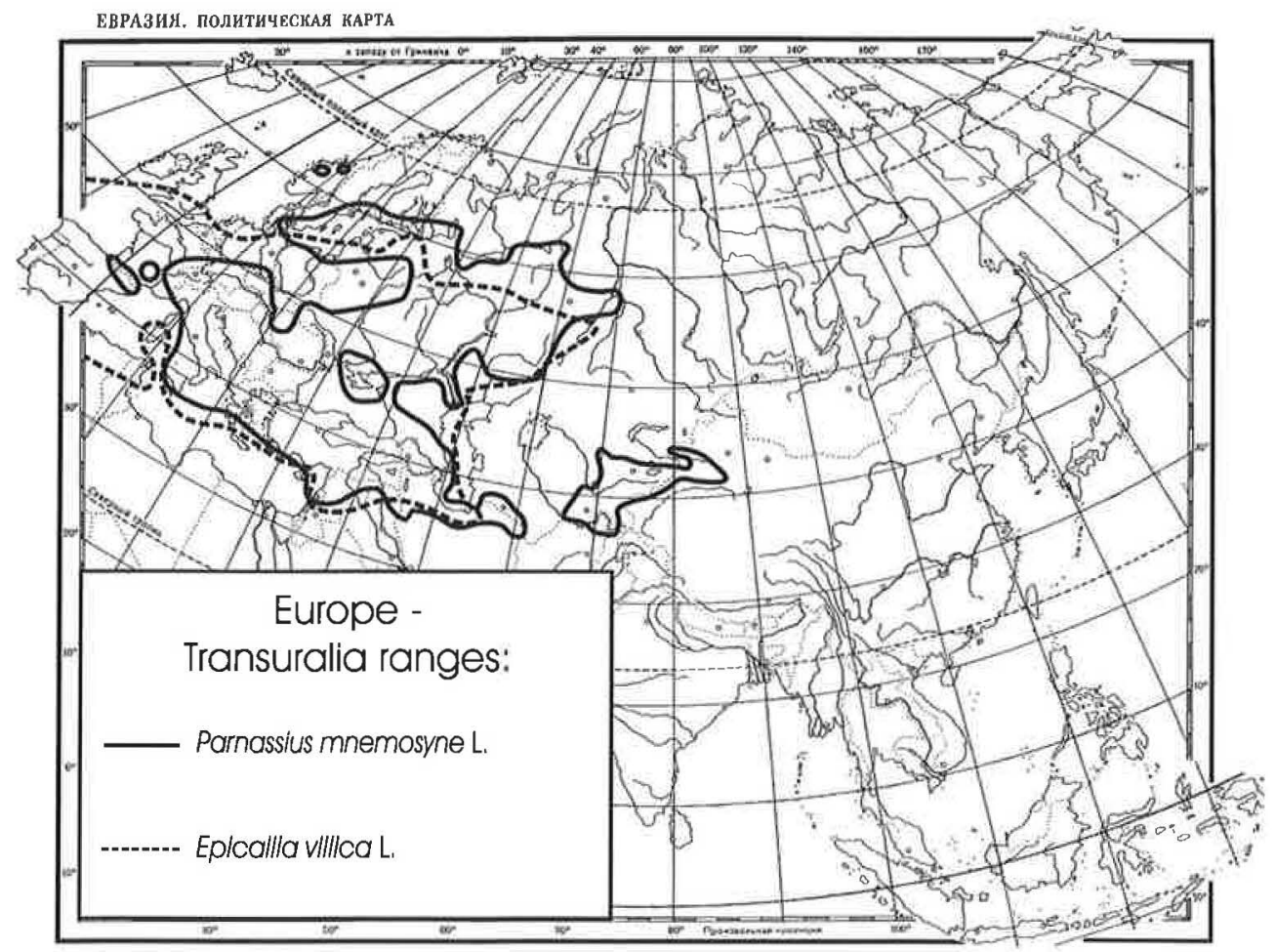

Fig. 8. Examples of Europe - Transuralia ranges. 


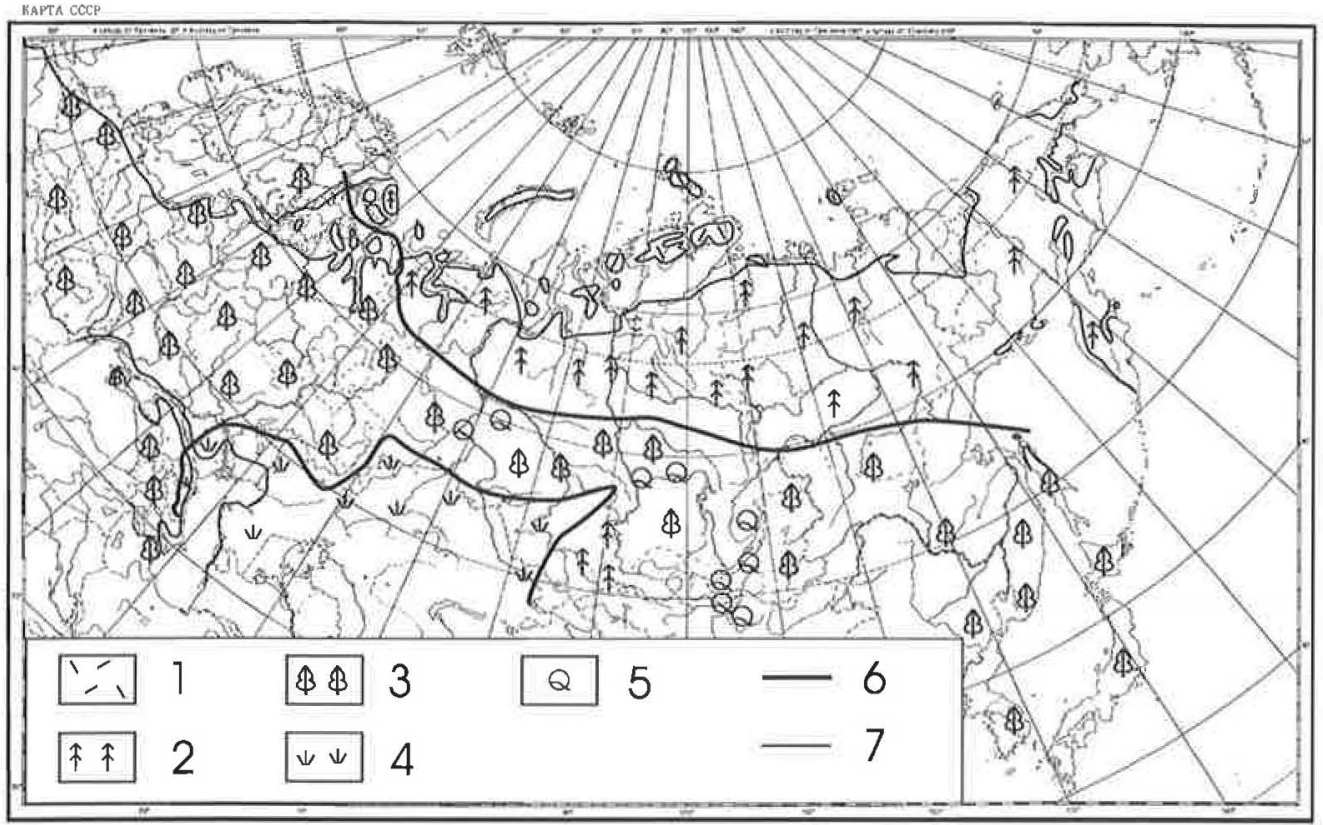

Fig. 9. Reconstruction of general zonality in the Climatic Optimum of the Upper Pleistocene (the Kazantseva = Mikulino = Riss-Würm Interglaciation). According to: Belova, 1985; Grichuk, 1989; Arkhipov, Volkova, 1994, and others. 1 , tundra; 2 , taiga; 3 , forests with participation of the broad-leaved trees; 4 , steppes; 5 , records of the oak pollen; 6 , borders of main vegetation types; 7 , coast line.

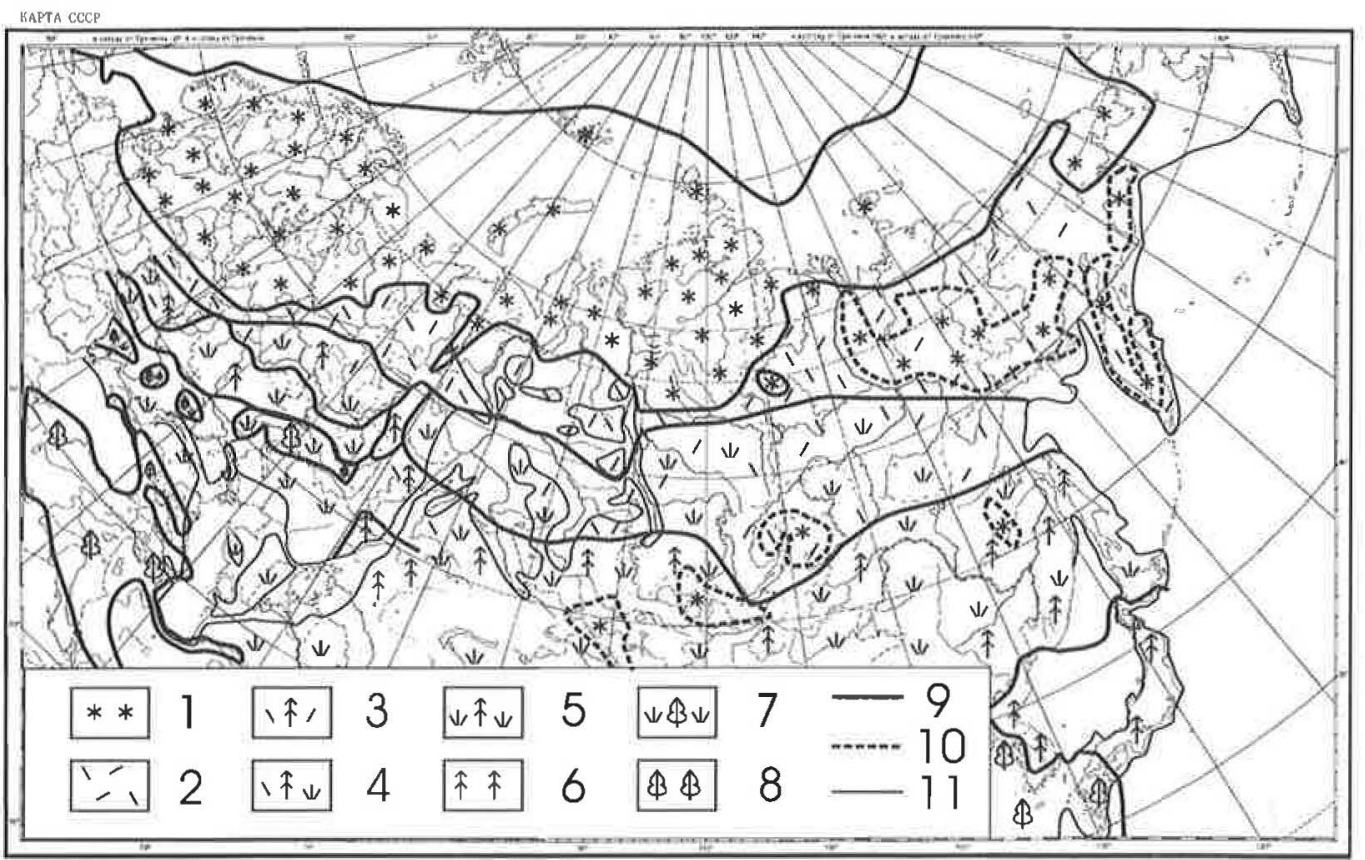

Fig. 10. Reconstruction of general zonality during the Maximum Glaciation of the Upper Pleistocene (the Sartan = Late Valdai = Late Zyryanka = Late Würm Glaciation). According to: Belova 1985; Grichuk 1989; Grosvald 1989; Nazarenko 1990; 1992; Arkhipov \& Volkova, 1994, and others. 1, ice-sheet and glaciers; 2, arid tundra; 3, cryophyte forest-tundra; 5 , forest steppe without the broad-leaved trees; 6 - local coniferous forests; 7 , forest-steppe with some broad-leaved trees; 8 , broad-leaved (nemoral) forests; 9 , borders of main vegetation types; 10 - borders of a diffuse mountain glaciation in NE Asia; 11, coast line. 


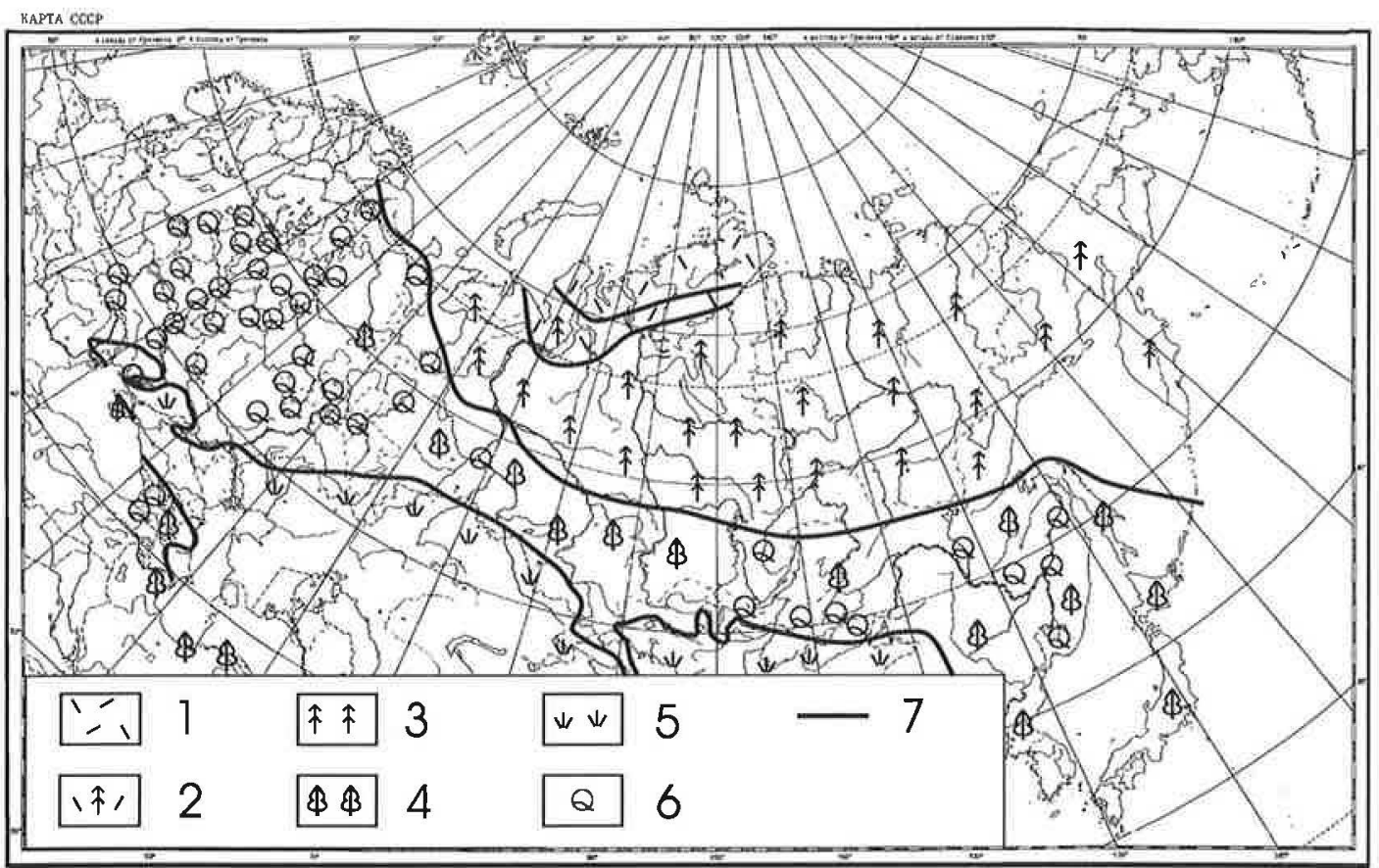

Fig. 11. Reconstruction of general zonality in the Climatic Optimum of the Holocene (the Atlantic period). According to: Belova, 1985; Grichuk, 1989; Arkhipov, Volkova, 1994, and others. 1, tundra; 2, forest-tundra; 3, taiga; 4, forests with participation of the broad-leaved trees; 5 , steppes and deserts; 6 , records of the oak pollen; 7 , borders of main vegetation types. 